University of South Carolina

Scholar Commons

Theses and Dissertations

2016

\title{
Alongshore Momentum Balance Over Shoreface-Connected Ridges, Fire Island, NY
}

Conor Ofsthun

University of South Carolina

Follow this and additional works at: https://scholarcommons.sc.edu/etd

Part of the Geology Commons

\section{Recommended Citation}

Ofsthun, C.(2016). Alongshore Momentum Balance Over Shoreface-Connected Ridges, Fire Island, NY.

(Master's thesis). Retrieved from https://scholarcommons.sc.edu/etd/3780

This Open Access Thesis is brought to you by Scholar Commons. It has been accepted for inclusion in Theses and Dissertations by an authorized administrator of Scholar Commons. For more information, please contact digres@mailbox.sc.edu. 


\title{
Alongshore Momentum Balance Over Shoreface-Connected Ridges, Fire Island, NY
}

by

\author{
Conor Ofsthun
}

Bachelor of Science

Tufts University, 2013

\author{
Submitted in Complete Fulfillment of the Requirements \\ For the Degree of Master of Science in \\ Geological Sciences \\ College of Arts and Sciences \\ University of South Carolina \\ 2016 \\ Accepted by: \\ George Voulgaris, Director of Thesis \\ Alexander Yankovsky, Reader \\ Ryan Rykaczewski, Reader
}

Lacy Ford, Senior Vice Provost and Dean of Graduate Studies 
C) Copyright by Conor Ofsthun, 2016 All Rights Reserved. 


\section{Acknowledgments}

Observational data was collected through the Fire Island Coastal Change project, a cooperative study supported by the US Geological Survey. Thanks to my advisor, Dr. George Voulgaris, for introducing me to the science of physical oceanography and guiding me through this thesis. Thanks to my committee, Dr. Alex Yankovsky and Dr. Ryan Rykaczewski, for their critiques. Lastly, thanks to the rest of the CPSD Lab, especially Zaid Alatabbi, Xiaodong Wu, and Doug Cahl for the patience and knowledge they offered me. 


\begin{abstract}
Bathymetric variations, such as shoreface-connected ridges (SFCRs), modify inner shelf circulation, altering the significance of and relationships between alongshore momentum balance terms. The inner shelf of Fire Island, NY provides a study site representative of SFCRs around the world. During the winter of 2014, hydrodynamic observations ( 12 m depth) from 6 ADCPs, 3 SeaGauge pressure sensors, 2 tide gauges, and 2 meteorological buoys were collected over a region of the inner shelf spanning a full wavelength of one such SFCR. Analysis of the data, under westward wind forcing, revealed a predominantly alongshore circulation with localized offshore (onshore) current veering over the SFCR crests (troughs). This circulation pattern, and its implied sediment dynamics, has long been recognized as the primary maintenance mechanism for SFCRs. Momentum balance analysis revealed local acceleration, advective acceleration, and bottom stress to be balanced by wind stress and large-scale $(>100 \mathrm{~km})$ pressure gradient force (correlation $r=0.75$ ). Current veering of alongshore flows is hypothesized to result from a frictional torque-induced rotation stemming from bottom stress variations across SFCRs.
\end{abstract}




\section{Table of Contents}

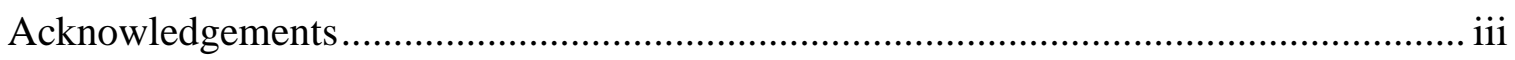

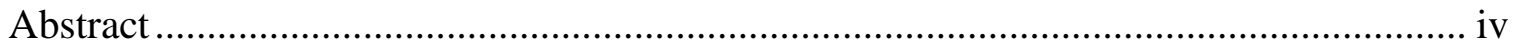

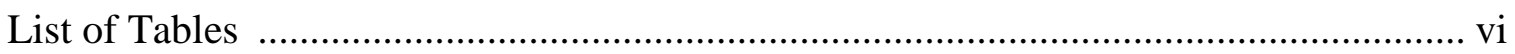

List of Figures .................................................................................................. vii

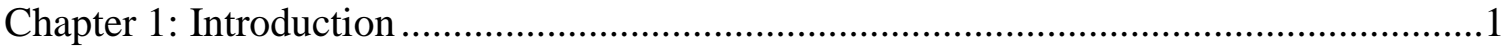

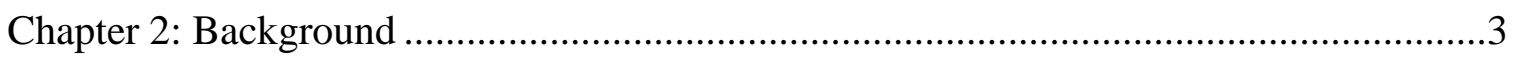

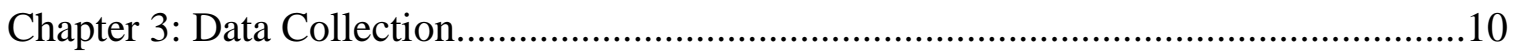

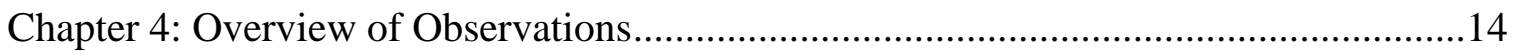

Chapter 5: Alongshore Momentum Balance Analysis......................................................22

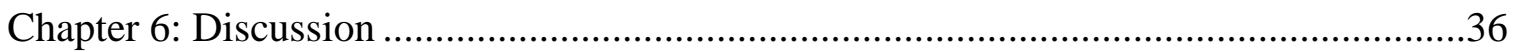

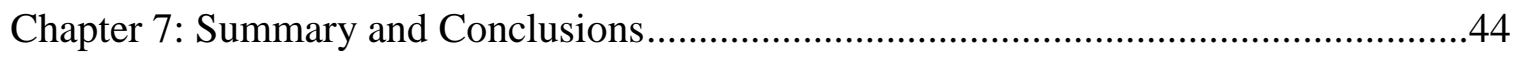

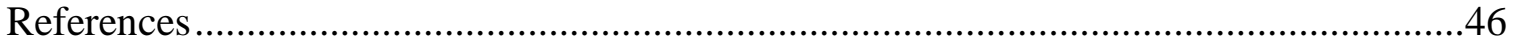




\section{List of Tables}

Table 3.1 - Details of instruments deployed off of Fire Island, NY during February 2014. The site numbering system carries on from Armstrong et al. (2015).

Table 4.1 - Depth-averaged, sub-tidal current velocity $(\mathrm{m} / \mathrm{s})$ and wind stress $\left(\mathrm{N} / \mathrm{m}^{2}\right)$ statistics. Currents are obtained at six sites and wind values span the length of those sites. SD is standard deviation. Principal axes are described in terms of standard deviation (Major and Minor) and orientation (absolute value of $\theta$, degrees clockwise from shoreline).

Table 5.1 - Site A correlation coefficients $(r=)$ of alongshore momentum balance terms (equation 1). Column 1 contains standard deviations $\left(10^{-6} \mathrm{~m} / \mathrm{s}^{2}\right)$ in addition to variable name.

Table 5.2 - Site B correlation coefficients $(r=)$ of alongshore momentum balance terms (equation 1). Column 1 contains standard deviations $\left(10^{-6} \mathrm{~m} / \mathrm{s}^{2}\right)$ in addition to variable name.

Table 5.3 - Site C correlation coefficients $(r=)$ of alongshore momentum balance terms (equation 1). Column 1 contains standard deviations $\left(10^{-6} \mathrm{~m} / \mathrm{s}^{2}\right)$ in addition to variable name.

Table 5.4 - Correlation coefficients ( $r=$ ) of alongshore momentum balance Force vs. Response, followed by the standard deviations $\left(10^{-6} \mathrm{~m} / \mathrm{s}^{2}\right)$ of residual acceleration (equation 10). Bold cells indicate the best correlation and lowest standard deviation in each respective row. Red cells indicate the combination of force terms and response terms which best balance equation 1 at each site. 


\section{List of Figures}

Figure 3.1: Map showing the study area (Fire Island, NY), inner shelf bathymetry ( $\mathrm{m}$ water depth) obtained during a USGS survey (Schwab et al. 2013), and sites of instrument deployment. The bottom right inset is a bathymetric profile of an imaginary transect drawn from sites 1 through 8 . Sites A, B, and C, represent the locations of momentum balance analysis.

Figure 4.1: Time-series, during yeardays 40-123 in 2014, of a) wind stress (oceanographic notation), b) atmospheric pressure, and c) air temperature averaged from sites 1 and 8 . Wave climate averaged from all 6 sites including d) significant wave height, e) peak (dotted) and mean (solid) wave period, and f) wave direction (oceanographic notation, waves come from). In a), north is oriented towards the top, and the coastline orientation is shown in black.

Figure 4.2: Surface (dashed) and bottom (solid) water properties at all 6 sites. a) Temperature $\left({ }^{\circ} \mathrm{C}\right)$, b) Salinity (ppt), and c) Density $\left(\mathrm{kg} / \mathrm{m}^{3}\right)$.

Figure 4.3: Time-series of depth-averaged, sub-tidal, a) alongshore (v) and b) crossshore $(\mathrm{u})$, wind stress (bold, $\mathrm{N} / \mathrm{m}$ ) and currents $(\mathrm{m} / \mathrm{s})$. The scale shown for winds is equal to that of currents.

Figure 4.4: Time-series at site 2 (SFCR crest) and site 6 (SFCR trough) of a) sea level $(\mathrm{m}), \mathrm{b})$ alongshore (blue, dashed) and cross-shore (red, bold) wind stress $\left(\mathrm{N} / \mathrm{m}^{2}\right)$, c) alongshore (blue, dashed) and cross-shore (red, bold) depth-averaged current $(\mathrm{m} / \mathrm{s})$, d) surface (green) and bottom (blue) density $\left(\mathrm{kg} / \mathrm{m}^{3}\right)$, and e) cross-shore current (color bar, $\mathrm{cm} / \mathrm{s}$ ) with depth (m). Black boxes highlight the nor'easter and tornado-induced storm discussed in section 4.1.

Figure 5.1: Time-series of sub-tidal, depth-averaged momentum balance terms $\left(\mathrm{m} / \mathrm{s}^{2}\right.$, equation 1): local acceleration (LA, blue), Coriolis acceleration (CA, green), advective acceleration (AA, red), wave-current combined bottom stress (BS, cyan), regional pressure gradient force (-PGF $\mathrm{PG}_{\mathrm{tg}}$, black), local pressure gradient force (-PGF $\mathrm{sg}$, gold), ideal pressure gradient force (-PGF , gray), wind stress (SS, blue), atmospheric force (red), and ocean response (green), for Site A (see Figure 3.1). 
Figure 5.2: Time-series of sub-tidal, depth-averaged momentum balance terms $\left(\mathrm{m} / \mathrm{s}^{2}\right.$, equation 1): local acceleration (LA, blue), Coriolis acceleration (CA, green), advective acceleration (AA, red), wave-current combined bottom stress (BS, cyan), regional pressure gradient force $\left(-\mathrm{PGF}_{\mathrm{tg}}\right.$, black), local pressure gradient force $\left(-\mathrm{PGF}_{\mathrm{sg}}\right.$, gold), ideal pressure gradient force (-PGFi, gray), wind stress (SS, blue), atmospheric force (red), and ocean response (green), for Site B (see Figure 3.1).

Figure 5.3: Time-series of sub-tidal, depth-averaged momentum balance terms $\left(\mathrm{m} / \mathrm{s}^{2}\right.$, equation 1): local acceleration (LA, blue), Coriolis acceleration (CA, green), advective acceleration (AA, red), wave-current combined bottom stress (BS, cyan), regional pressure gradient force $\left(-\mathrm{PGF}_{\mathrm{tg}}\right.$, black), local pressure gradient force $\left(-\mathrm{PGF}_{\mathrm{sg}}\right.$, gold), ideal pressure gradient force (-PGF $\mathrm{i}$, gray), wind stress (SS, blue), atmospheric force (red), and ocean response (green), for Site C (see Figure 3.1)

Figure 6.1: Time-series of sub-tidal, depth-averaged momentum balance force (green) and response (blue) $\left(\mathrm{m} / \mathrm{s}^{2}\right.$, equation 1$)$, and residual acceleration (red) $\left(\mathrm{m} / \mathrm{s}^{2}\right.$, equation 19). Time-series are an average of the best balance of momentum terms at sites $\mathrm{A}, \mathrm{B}$, and $\mathrm{C}$.

Figure 6.2: Schematic showing the potential_mechanisms of mass conservation and frictional torque induced current deflection over a ridge crest, plan-view. a) Onshore deflection b) Offshore deflection. Red arrows represent the magnitude of bottom stress; green arrows represent pressure gradient force; and, black arrows represent the current streamline of a water parcel (blue box). The coast is represented as the horizontal sand color at the top of the diagram. SFCRs are represented as sand colored ellipses oriented obliquely from the coast. 


\section{Chapter 1: Introduction}

The inner shelf has been the focus for numerous field studies of alongshore flows adjacent to straight stretches of coastline and above relatively uniform bathymetries. The inner shelf is defined as the region offshore of the surf zone where surface and bottom boundary layers overlap (Lentz 1995). The dynamics in this region are dominated by the forcing of alongshore wind stress and alongshore pressure gradients, balanced by bottom stress response (Pettigrew 1980, Lentz and Winant 1986, Lentz 1994, Lentz et al. 1999, Liu and Weisberg 2005, Gutierrez et al. 2006, Fewings and Lentz 2010, Lentz and Fewings 2012). Coastal and bathymetric variations modify inner shelf circulation and the momentum balance (Dragos and Aubrey 1990, Yankovsky and Garvine 1998, van de Meene and van Rijn 2000a, Kirincich and Barth 2009, Kumar et al. 2013).

One such bathymetric variation is shoreface-connected ridges (SFCRs). SFCRs and similar shoals are found globally, including the Brazilian, Argentinian, Canadian, Dutch, and US Atlantic continental shelves (Figueiredo et al. 1982, Parker et al. 1982, Hoogendoorn and Dalrymple 1986, Caston 1972, McBride and Moslow 1991, respectively). SFCRs are found on storm-dominated coasts and typically exist as sandy, rhythmic features of about $10 \mathrm{~km}$ length, 2-4 km spacing, 1-10 m amplitude, and $30^{\circ}$ orientation oblique from the shoreface (Swift et al. 1978, Warner et al. 2014). SFCRs potentially enhance wave attenuation and can be a source of sediment for beach nourishment and cross-shore sediment transport, all of which affect the fate of beaches

(Schwab et al. 2013). Models studying SFCR origins and maintenance mechanisms have 
identified sediment deposition on ridge crests due to an offshore veering and slowdown of alongshore flows by up-current oriented, transverse sloping bars as the positive feedback cycle leading to ridge growth (Trowbridge 1995, Falqués et al. 1998, Calvete et al. 2001). The physical cause of current veering has been hypothesized to be the result of frictional torques and mass conservation (Zimmerman 1981, van de Meene and van Rijn 2000a, Warner et al. 2014, Ribas et al. 2015).

In 2014, the US Geological Survey performed the Fire Island Coastal Change Processes Project field experiment on the inner shelf of Fire Island, NY, an area characterized by SFCRs (Armstrong et al. 2015). In this study, oceanographic and meteorological data were collected and the data were analyzed in the context of local, sub-tidal alongshore flows. These data are used here in an attempt to: (a) describe the pattern of circulation on the inner shelf of Fire Island, NY above a series of SFCRs; (b) provide a dynamic analysis of atmospheric force and oceanic response through the use of momentum balance analysis; and (c) reveal the role of SFCRs in coastal current circulation. The remainder of this thesis is organized as follows. In Chapter 2, we will provide a background of geologic and oceanographic studies on Long Island, NY and its continental shelf. In Chapter 3, the study site and data collection program is presented, while Chapter 4 presents a descriptive view of the collected information. This is followed by a dynamic analysis of alongshore flows and details on how SFCRs influence the balance of hydrodynamic forcing (Chapter 5). The findings are discussed in Chapter 6 with the final conclusions being presented in Chapter 7. 


\section{Chapter 2: Background}

\subsection{Geologic Setting of Long Island, NY and SFCRs}

The coastline and inner shelf of Fire Island and Long Island, NY have been heavily researched since the 1970's (Flint 1971, Lavelle et al. 1978, Rampino 1979, Swift and Field 1981, Rampino and Sanders 1981, Niedoroda and Swift 1981, Swift and Moslow 1982, McBride and Moslow 1991, Kana 1995, Foster et al. 1999, Rosati et al. 1999, Schwab et al. 2000, Hapke et al. 2010, Lentz et al. 2013, Schwab et al. 2013). Long Island, NY is an island formed from the seaward limit of the Wisconsin glacier depositing a large terminal moraine (Flint 1971). Rampino (1979) tracked the submergence of Long Island and the geographic transitions which occurred through Holocene transgression. Rampino and Sanders (1981) extended the geologic work to find a stationary up-building of Long Island barriers with transgression from 9000 to 7000 years ago. Then, sea level rise became rapid and the surf zone overstepped the barriers causing shoreface retreat and new barrier growth to this day. Swift and Moslow (1982) rejected the idea of barrier overstepping and instead suggested barrier migration through

erosional shoreface retreat. A series of SFCRs on the Delaware-Maryland inner shelf are alsobelieved to have developed during Holocene transgression (Swift and Field 1981).

Offshore of the barrier island is a series of shoreface-connected ridges (SFCRs) which extend $10 \mathrm{~km}$ into the inner shelf at a $30^{\circ}$ angle clockwise from the shoreface. SFCR orientation is hypothesized to result from a faster ridge migration close to shore (Swift and Field 1981). Fire Island's SFCRs are well-sorted with medium-fine grained 
sand, and have an average amplitude of approximately $8 \mathrm{~m}$ and spacing of $3 \mathrm{~km}$ (Warner et al. 2014). SFCRs have been recognized globally, but their form varies between tidal and storm dominated shelves, Long Island being storm-dominated (Dragos et al. 1990, Lavelle et al. 1978). 259 SFCRs have been identified along the US Atlantic Coast (McBride and Moslow 1991). Cross-shore variations of ridge slopes, mud lenses, megaripples, and sand waves led Swift and Field (1981) to conclude that high-frequency wave surge and storm effects are less significant in offshore ridge development in comparison to mean current. McBride and Moslow (1991) described SFCRs as a result of ebb-tidal deltas, transgression, wave dominated barrier islands, and migrating tidal inlets.

On Fire Island, the dominant direction of sediment transport is towards the west (Kana 1995). Although Fire Island has been relatively stable for the past 1200 years, sediment budget analysis determined a net loss of $249,000 \mathrm{~m}^{3} / \mathrm{yr}$ of sediment from Fire Island to the west. An offshore sediment source has been hypothesized to close this gap, though the forcing has not been recognized (Rosati et al. 1999, Hapke et al. 2010). Niedoroda and Swift (1981) found an asymmetric cross-shore bottom orbital velocity which forces sediment onshore at depths under $10 \mathrm{~m}$, but it is possibly not significant enough to fill the gap. Some research has suggested that the sediment deficit may be filled by onshore sediment transport from SFCRs. If this is true, the relatively unchanging volume of SFCRs may be explained by nor'easter causing a submerged Cretaceous headland offshore of Watch Hill to provide maintenance sediment to the SFCRs located to its west (Foster et al. 1999, Schwab et al. 2000). Kana et al. (2011) argue there is a lack of evidence for this onshore sediment transport. Lentz et al. (2013) were able to use maps 
and images to predict overwash areas of Fire Island and argue for inner shelf onshore sediment transport.

These geologic studies are important for the decision to mine SFCRs for beach nourishment because if beach stabilizing onshore sediment transport from SFCRs is minimal, sediment mining becomes more appealing. However, fundamentally, these studies aim to solve our understanding of Fire Island and its future through typically qualitative hypotheses rather than the physics of waves, currents, and sediment transport. This brings us to the oceanographic approaches in understanding Fire Island.

\subsection{Oceanographic Conditions of Long Island, NY and SFCRs}

Oceanographic studies are recently showing promise of accurately representing the coastal processes of the Long Island shelf and Fire Island's SFCRs (Beardsley and Butman 1974, Csanady 1976, Scott and Csanady 1976, Beardsley et al. 1977, Semter and Mintz 1977, Csanady 1978, Winant and Beardsley 1979, Beardsley and Winant 1979, Han and Mayer 1981, Huthnance 1982, Churchill 1985, Chapman and Beardsley 1988, Dragos and Aubrey 1990, Trowbridge 1995, Falqués et al. 1998, Calvete et al. 2001, Garnier et al. 2006, Lane and Restrepo 2007, Vis-Star et al. 2007, Nnafie et al. 2014, Nnafie et al. 2014, Warner et al. 2014). Beardsley and Butman (1974) began to focus on the continental shelf of the Mid-Atlantic Bight, which spans from Cape Cod, MA to Cape Hatteras, NC. They recognized a generally geostrophically balanced, large-scale asymmetry of currents which flow strongly to the west during easterly winds, but weakly to the east during westerly winds. These observations come from storm events which are thought to drive the mean current. Also on the outer shelf of the Mid-Atlantic Bight, Csanady (1978) and Beardsley and Winant (1979) tackled the issue of what drives the 
dominantly southwestward flowing alongshelf currents. Predominant wind stress opposes this current thus indicating that an alongshore pressure gradient forces the current. The St. Lawrence fresh water input potentially creates an alongshore pressure gradient, though the lack of seasonality in the southwestward current suggests this is not the driving mechanism. Therefore, they put forth that this is a boundary layer responding to large-scale circulation in the western North Atlantic Ocean in the form of a geostrophic current, produced by an alongshelf pressure gradient at the shelf break, which travels towards the southwest until it re-enters the Gulf Stream at Cape Hatteras point. Semtner and Mintz (1977), successfully modeled this pressure gradient when studying the Gulf Stream in the Mid-Atlantic Bight. The bulk of the water present off the coast of Fire Island comes from the extended, along-shelf buoyant current which originates off the coast of Greenland (Chapman and Beardsley, 1989). Churchill (1985) studied the crossshore dynamics of the Long Island shelf and recognized a two-layer flow with a fluctuating onshore-offshore upper layer flow dependent upon longshore wind stress. Late summer circulation, when stratification is typically at its peak, also experienced a cross-shore flow due to density gradients.

In the mid-shelf of Long Island, Csanady (1976), using data from Scott and Csanady (1976), put forth a real data solution to the Navier-Stokes based, steady-state equations outlined by Stommel and Leetmaa (1972). Csanady found that steady-state analysis is effective, but, at the time, was too simplified to fully represent mean circulation. He described the mean circulation as straightforward, where current velocities react with no lag to wind stress and pressure gradient force. Beardsley et al. (1977) focused on bottom pressure fluctuations in the Mid-Atlantic Bight. They 
recognized meteorologically forced coastally-trapped edge waves with a period of 5-7 hours, and a dissipation rate of 1-2 periods.

The inner shelf of Fire Island has attracted the most attention. Here, a 1993-2012 analysis found south-southwesterly winds to be predominant, but west-northwesterly and northeasterly winds to be strongest (Warner et al. 2014). The dominant storm wave direction comes from the east and southeast which drives a longshore sediment transport from east to west (Lentz et al. 2013). The mean tidal range, $1.3 \mathrm{~m}$, is considered microtidal (Lentz et al. 2013). Lavelle et al. (1978) recognized a dominantly westward flowing current during storms as a correlation with SFCRs and their upstream and shore-oblique orientation. Han and Mayer (1981) studied SFCRs and recognized minor current veering by ridges, but were not confident in the results to put forth any maintenance mechanism. Swift and Field (1981) declared SFCRs to be a consequence of initial topography and the resulting bottom shear stress distribution. Caston (1972) and Huthnance (1982) studied linear sand bank maintenance mechanisms and, although the North Sea's current is tidally-dominated, unlike Fire Island's storm-dominated current, the mechanism put forth is relatable in the importance of increased bottom-drag over ridge crests. Dragos and Aubrey (1990) reaffirmed the unimportance of tidal flows, and the importance of storm driven flows in the maintenance of SFCRs through field measurements. Additionally, current veering on SFCR ridges was measured, however no further suggestion of its role in SFCR development was put forth.

Returning since Huthnance (1982), modeling of SFCRs and linear sand banks became the main method of study. Trowbridge (1995) successfully modeled SFCR growth. He identified the maintenance mechanism as a result of the dominant westward 
flowing currents on a transverse slope which are deflected offshore by ridge crests, causing current convergence, a decrease is sediment carrying capacity, and sediment deposition on ridge crests. Falqués et al. (1998) also successfully modeled the formation of SFCRs, and attributed ridge maintenance to offshore current veering and sediment convergence. Through varying tidal and meteorological strength, Calvete et al. (2001) recognized five possible sand ridge formations, two of which make up the bulk of realworld observations. They suggested that SFCRs formed in the category of weak tides, storm dominance, strong steady flows, and a transverse slope, just as Trowbridge (1995) had found. Calvete et al. (2001) furthered Trowbridge's description by finding that wave stirring is necessary for freeing sediment for advection and deposition. Suspended-load transport accounts for ridge growth, and bed-load transport, depositing on the downstream face, accounts for ridge migration. Garnier et al. (2006) fine-tuned SFCR models by including a finite-amplitude which promotes gravitational down-slope transport. This inclusion is a step towards understanding nonlinear bar dynamics such as merging, longshore asymmetry, and jet-like rip currents due to differential wave breaking over shoals and troughs. The influence of waves on SFCRs has developed into a key area of focus (Hayes et al. 2004, Lane and Restrepo 2007). Vis-Star et al. (2007) described wave orbital velocity convergence and divergence which cause ridge maintenance, presenting the possibility of ridge growth without a transverse slope. Warner et al. (2014) studied in-situ current measurements of Fire Island SFCRs at water depths near $20 \mathrm{~m}$. They confirmed model predictions of ridge maintenance mechanisms during downwelling favorable winds, and found that deconstructive mechanisms occur during upwelling favorable winds. Additionally, they modeled momentum balance terms and 
found the current veering resulted from a cross-shore variation of alongshore advective accelerations setting up cross-shore pressure gradients.

Two papers by Nnafie et al. (2014a and 2014b), using models for SFCR growth and maintenance, looked towards larger issues such as SFCR sand extraction and SFCR fate under sea level rise. Results showed that after dredging, SFCRs recover over decadal timescales, but never reach their original sand volume. Additionally, SFCRs will maintain their relative position to mean sea level during sea level rise, but if transgression rates are too fast SFCRs will drown and new ridges will form as the shoreface retreats. 


\section{Chapter 3: Data Collection}

Over the period of February $4^{\text {th }}$-May $7^{\text {th }}, 2014$, the US Geological Survey conducted the Fire Island Coastal Change Processes project aimed at revealing the interactions of wind, wave, current, and sediment transport processes on the inner shelf of Fire Island, NY. Fire Island is a $0.5-1 \mathrm{~km}$ wide and $80 \mathrm{~km}$ long barrier island just seaward of Long Island, NY. The majority of the island is part of the Fire Island National Seashore, regulated by the National Park Service; however, it is also highly populated as there are 17 private communities developed in the area (Lentz et al. 2013). The nearly straight coastline is oriented $74^{\circ} \mathrm{N}$. The inner shelf bathymetry consists of three distinct regions, from east to west: a generally unperturbed slope, a glacial outwash lobe, and SFCRs, the third of which was the location for instrument deployment ( 12 m depth) (Figure 3.1). The glacial outwash lobe is believed to be the source of sediment for growing SFCRs (Schwab et al. 2000). Five sites (Figure 3.1, Site 1, 2, 6, 7, and 8) were instrumented, capturing a full wavelength of a SFCR, site 2 being located on a SFCR crest, site 6 in a trough, and site 7 on a successive crest. A sixth deployment (site 3) was located approximately $1 \mathrm{~km}$ offshore from the others ( 16 $\mathrm{m}$ depth).

Observational data were acquired from MSI G200 Buoys, bottom-mounted acoustic Doppler current profilers (ADCPs), and Seagauge pressure sensors (Table 3.1). Additionally, tide gauge and atmospheric pressure data were obtained from NOAA stations at Montauk, NY and Sandy Hook, NJ which span the length of Long Island, NY plus the Hudson Bay (>180 km). Where Sandy Hook, NJ lacked atmospheric pressure 
data, the nearby NOAA station, Robbins Reef, NJ, was substituted

(http://tidesandcurrents.noaa.gov/).

Prior to analysis, the data were manually checked for skipped, repetitive, and excessive sampling. Spikes, defined as data points exceeding the $2^{\text {nd }}$ standard deviation, were removed and replaced with an average of adjacent data points. All data were lowpass filtered, removing variations with periods shorter than 33 hours, in order to isolate sub-tidal variations (Rosenfeld 1983). The reference frame was rotated $74^{\circ}$ clockwise from north, the orientation of Fire Island's coastline, to create a positive alongshore (y) axis pointing east-northeast, and a positive cross-shore (x) axis pointing south-southeast (offshore) (see Figure 3.1).

Meteorological data were collected at sites 1 and 8, approximately $7 \mathrm{~km}$ apart, however site 8 faltered and fell short of the expected collection period by about one month. In a comparison of sites 1 and 8, a minor wind velocity phase lag was seen. Sites 1 and 8 were averaged to create a wind data set that represented wind conditions over the whole of Fire Island. Where site 8 lacked data, data from site 1 were used alone. Wind velocities were converted to the standard $10 \mathrm{~m}$ velocities using the wind profile power law (Peterson and Hennessey 1978). Pressure sensor observations during the initial 164 hours of data were illogical, possibly from tripod settling, and were excluded.

Lastly, different sensors sampled at different intervals and began at different hours (see Table 3.1). In order to proceed with momentum balance analysis, all data were resampled or interpolated to on the hour intervals from February $8^{\text {th }}$ to May $3^{\text {rd }}, 2014$, an 83 day period hereby referred to as yeardays beginning from January 1, 2014. 
Table 3.1 - Details of instruments deployed off of Fire Island, NY during February 2014. The site numbering system carries on from Armstrong et al. (2015).

\begin{tabular}{|c|c|c|c|c|c|}
\hline Site & Instrument Type & $\begin{array}{c}\text { Mean } \\
\text { ADCP } \\
\text { Water } \\
\text { Depth (m) }\end{array}$ & $\begin{array}{c}\text { Measurement } \\
\text { Height, m } \\
\text { above seabed } \\
\text { (ADCP } \\
\text { height+1 } \\
\text { bin dist) }\end{array}$ & $\begin{array}{c}\text { Sampling } \\
\text { Interval (s) }\end{array}$ & $\begin{array}{c}\text { Deployment } \\
\text { Dates }\end{array}$ \\
\hline 1 A & MSI G200 Buoy & NA & NA & 900 & $\begin{array}{c}02 / 04- \\
05 / 07 / 14\end{array}$ \\
\hline 1 & $\begin{array}{c}\text { ADCP,Seagauge } \\
\text { Pressure Sensor }\end{array}$ & 12.3 & $1.28+.83$ & 300,3600 & $\begin{array}{c}02 / 07- \\
05 / 07 / 14\end{array}$ \\
\hline 2 & ADCP & 12.2 & $2.08+1.06$ & 1800 & $\begin{array}{c}02 / 07- \\
05 / 05 / 14\end{array}$ \\
\hline 3 & ADCP & 16.4 & $2.13+.95$ & 300 & $\begin{array}{c}02 / 07- \\
05 / 05 / 14\end{array}$ \\
\hline 6 & ADCP & 12.7 & $0.82+0.83$ & 300 & $\begin{array}{c}02 / 07- \\
05 / 03 / 14\end{array}$ \\
\hline 7 & $\begin{array}{c}\text { ADCP,Seagauge } \\
\text { Pressure Sensor }\end{array}$ & 12.2 & $1.29+0.95$ & 300,3600 & $\begin{array}{c}02 / 07- \\
05 / 07 / 14\end{array}$ \\
\hline $8 \mathrm{E}$ & MSI G200 Buoy & NA & NA & 900 & $\begin{array}{c}02 / 04- \\
05 / 07 / 14\end{array}$ \\
\hline 8 & $\begin{array}{l}\text { ADCP,Seagauge } \\
\text { Pressure Sensor }\end{array}$ & 12.6 & $1.28+0.83$ & 300,3600 & $\begin{array}{c}02 / 07- \\
05 / 07 / 14\end{array}$ \\
\hline
\end{tabular}




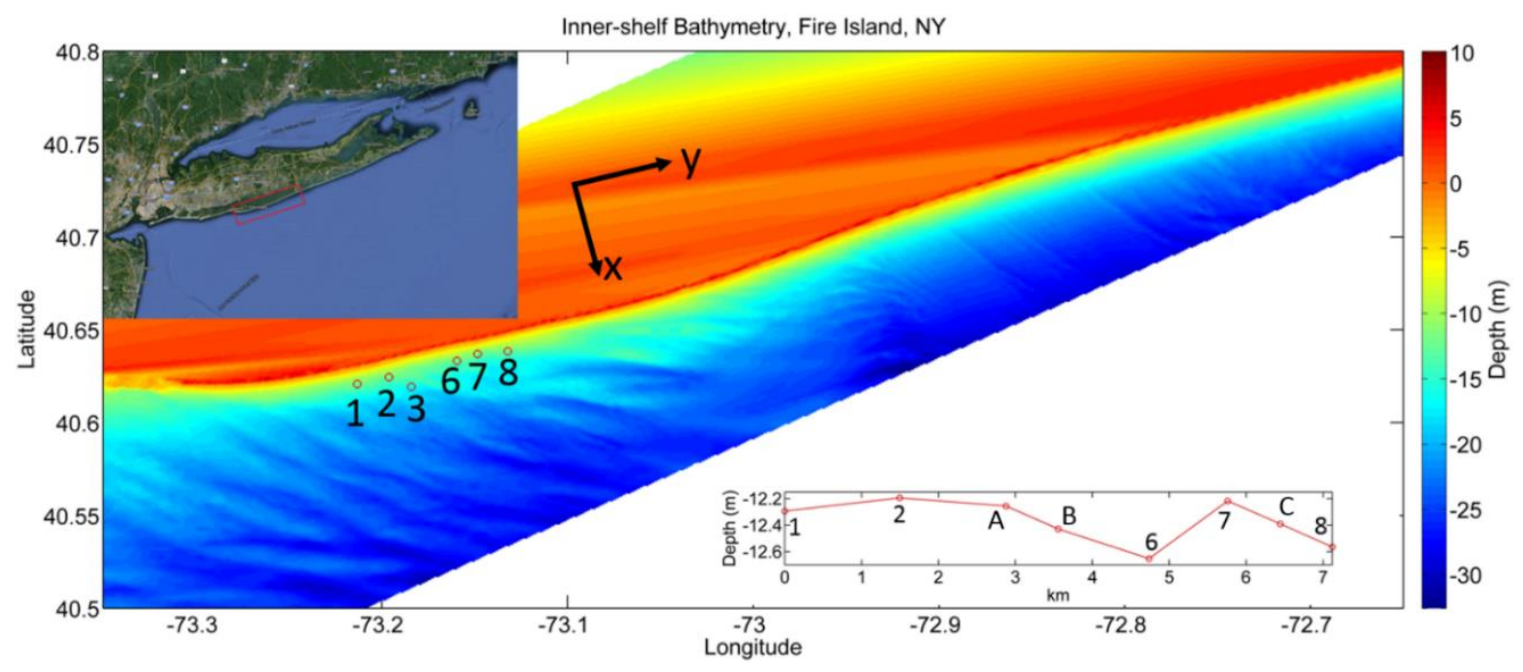

Figure 3.1: Map showing the study area (Fire Island, NY), inner shelf bathymetry (m water depth) obtained during a USGS survey (Schwab et al. 2013), and sites of instrument deployment. The bottom right inset is a bathymetric profile of an imaginary transect drawn from sites 1 through 8 . Sites A, B, and C, represent the locations of momentum balance analysis. 


\section{Chapter 4: Overview of Observations}

\subsection{Meteorological Conditions}

During the period of this study, Fire Island endured maximum low-pass filtered wind speeds of $19.6 \mathrm{~m} / \mathrm{s}$ and minimum of $0.3 \mathrm{~m} / \mathrm{s}$. Winds blew onshore $34 \%$ of the time, offshore $23 \%$ of the time, westward alongshore $16 \%$ of the time, and eastward alongshore $27 \%$ of the time. A low-pressure, blizzard-causing nor'easter entered the study region on February $13^{\text {th }}$ and can be seen in the high wind speeds, drop in atmospheric pressure, increase in air temperature, and high significant wave height of yearday 45-46 (Figure 4.1). A storm which generated a tornado outbreak in the central and southeastern United States led to a landslide-causing event with high southerly winds from April 30-May 1, (yearday 120-121). Other high wind events were typically associated with low-pressure systems, a common pattern along the eastern United States (Austin and Lentz 1999), though this pattern was not perfectly consistent.

Water density changes depended mostly on changes of salinity, indicating freshwater inputs, possibly from the Hudson River, the Connecticut River, and rain (Figure 4.2). Lentz (2008) found that, during winter, the mid-Atlantic Bight's water column is generally weakly stratified, as is the case during our study; and, the role of density in circulation is generally minor (see section 5.2).

\subsection{Oceanographic Conditions}

In this section, we will address inner shelf circulation in terms of depth-averaged, sub-tidal currents, unless otherwise noted. Alongshore and cross-shore current statistics 
are presented in Table 4.1 and time-series are presented in Figure 4.3. Alongshore current variations strongly correlate with respect to alongshore wind velocity variations $(\mathrm{r}=0.76)$, as opposed to cross-shore current observations which do not vary significantly with respect to cross-shore wind velocity variations $(\mathrm{r}=0.35)$. Neither alongshore nor crossshore currents correlate significantly with their respective orthogonal winds $(r=-0.01, r=-$ 0.14 , respectively). Alongshore currents correlate positively and strongly from site to site (r>0.97). Conversely, the cross-shore currents above an SFCR crest (site 2) correlate negatively ( $\mathrm{r}=-0.82$ ) with cross-shore currents above an SFCR trough (site 6) (see Figure 3.1 for site locations). In other words, under the same wind forcing, and the same alongshore current flows, cross-shore currents flow in opposite directions on SFCR crests versus SFCR troughs. This negative correlation of cross-shore currents over SFCRs has been observed and modelled extensively and holds profound implications for the local current dynamics, sediment transport, and ultimately SFCR growth and maintenance (Trowbridge 1995). Principal component analysis was employed to better identify the angle of current veering, however the alongshore current component was too dominant to allow for discerning the small scale veering.

During westward (negative alongshore) downwelling favorable winds, a sea surface set up, as high as $0.5 \mathrm{~m}$, was observed (Figure 4.4). Similarly, during eastward (positive alongshore) upwelling favorable winds, a sea surface set down, as low as $0.3 \mathrm{~m}$, was observed. As alongshore currents flowed westward (eastward) over up-current (down-current) oriented SFCRs, currents veered offshore (onshore) as depth decreased towards SFCR crests, and currents veered onshore (offshore) as depth increased towards 
SFCR troughs (see Chapter 6). The most extreme of these two scenarios were observed on yeardays 45 and 120 (see Figure 4.4).

We investigated the variation of sub-tidal currents with depth, two examples of which, cross-shore currents at sites 2 and 6, are exhibited in Figure 4.4. Near surface, alongshore currents correlate well ( $r>0.87)$ with near bottom, alongshore currents. Crossshore flows vary strongly with depth and have no consistent correlation between near surface and near bottom flows. Oftentimes, the strongest cross-shore flow originates near the bed, though not always, likely depending on whether cross-shore winds enhance or dampen the cross-shore flows that are expected in the SFCR regime. 
Table 4.1 - Depth-averaged, sub-tidal current velocity $(\mathrm{m} / \mathrm{s})$ and wind stress $\left(\mathrm{N} / \mathrm{m}^{2}\right)$ statistics. Currents are obtained at six sites and wind values span the length of those sites. SD is standard deviation. Principal axes are described in terms of standard deviation (Major and Minor) and orientation (absolute value of $\theta$, degrees clockwise from shoreline).

\begin{tabular}{|c|c|c|c|c|c|c|c|c|c|c|c|}
\hline & \multicolumn{4}{|c|}{ Alongshore Wind/Current } & \multicolumn{4}{|c|}{ Cross-shore Wind/Current } & \multicolumn{3}{|c|}{ Principal Axes } \\
\hline Site & Mean & SD & $\operatorname{Max}$ & Min & Mean & $\mathrm{SD}$ & Max & Min & Major & Minor & $\theta$ \\
\hline Win & 0.010 & 0.114 & 0.488 & 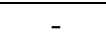 & 0.015 & 0.089 & 0.683 & - & 0.102 & 0.039 & 1.5 \\
\hline $\mathrm{d}$ & 9 & 3 & 3 & $\begin{array}{c}0.729 \\
5\end{array}$ & 0 & 8 & 4 & $\begin{array}{c}0.275 \\
2\end{array}$ & 7 & 4 & 2 \\
\hline $\begin{array}{c}\text { Site } \\
1\end{array}$ & 0.0196 & 0.1447 & 0.3841 & $\begin{array}{c}- \\
0.5172\end{array}$ & 0.0083 & 0.0098 & 0.0501 & $\begin{array}{c}- \\
0.0120\end{array}$ & 0.1446 & 0.0003 & 1.88 \\
\hline $\begin{array}{c}\text { Site } \\
2\end{array}$ & 0.0191 & 0.1324 & 0.3462 & $\begin{array}{c}- \\
0.4610\end{array}$ & 0.0024 & 0.0459 & 0.1755 & $\begin{array}{c}- \\
0.1049\end{array}$ & 0.1253 & 0.0148 & 1.83 \\
\hline $\begin{array}{c}\text { Site } \\
3 \\
\end{array}$ & 0.0219 & 0.1164 & 0.3179 & $\begin{array}{c}- \\
0.3623 \\
\end{array}$ & 0.0089 & 0.0181 & 0.0616 & $\begin{array}{c}- \\
0.0470\end{array}$ & 0.1155 & 0.0023 & 1.78 \\
\hline $\begin{array}{c}\text { Site } \\
6\end{array}$ & 0.0199 & 0.1482 & 0.3937 & $\begin{array}{c}- \\
0.5031\end{array}$ & 0.0131 & 0.0247 & 0.0773 & $\begin{array}{c}- \\
0.0673\end{array}$ & 0.1468 & 0.0035 & 1.82 \\
\hline $\begin{array}{c}\text { Site } \\
7\end{array}$ & 0.0132 & 0.1412 & 0.3891 & $\begin{array}{c}- \\
0.4925\end{array}$ & 0.0090 & 0.0084 & 0.0510 & $\begin{array}{c}- \\
0.0056\end{array}$ & 0.1412 & 0.0001 & 1.79 \\
\hline $\begin{array}{c}\text { Site } \\
8\end{array}$ & 0.0144 & 0.1420 & 0.3345 & $\begin{array}{c}- \\
0.4846\end{array}$ & 0.0075 & 0.0129 & 0.0582 & $\begin{array}{c}- \\
0.0350\end{array}$ & 0.1416 & 0.0009 & 1.79 \\
\hline
\end{tabular}


a)

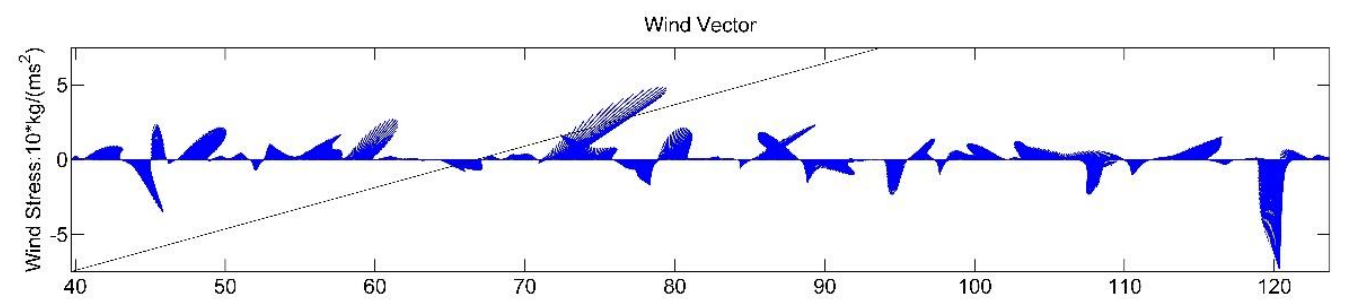

b)

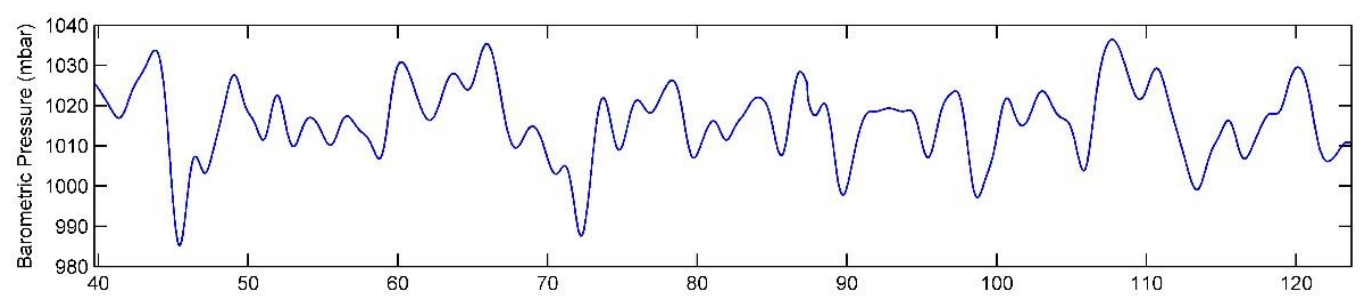

c)

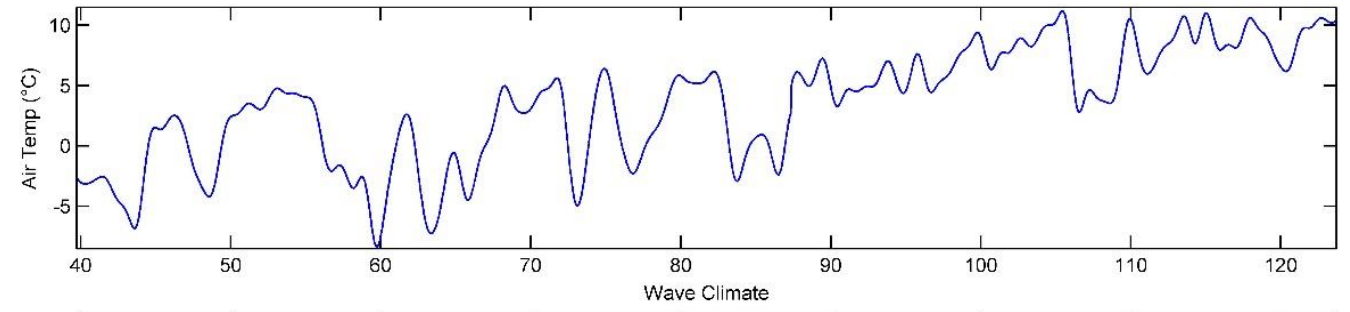

d)

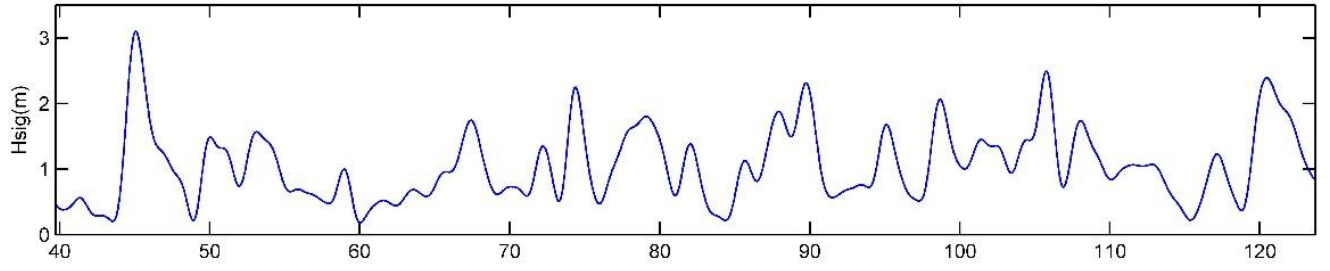

e)

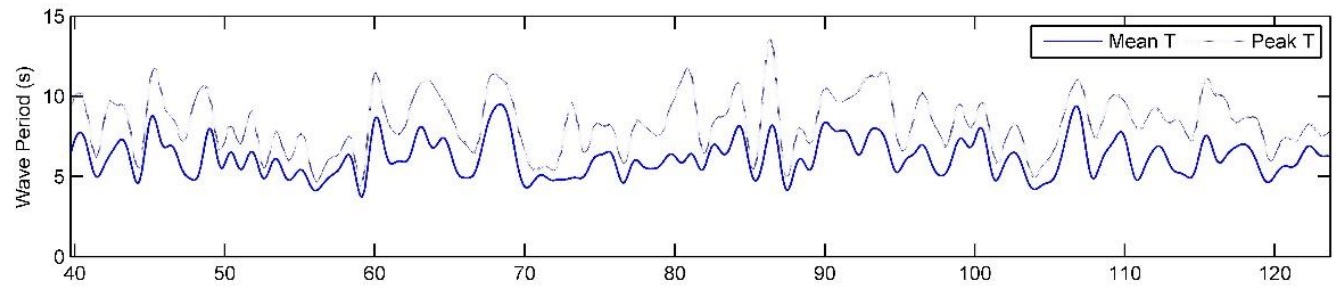

f)

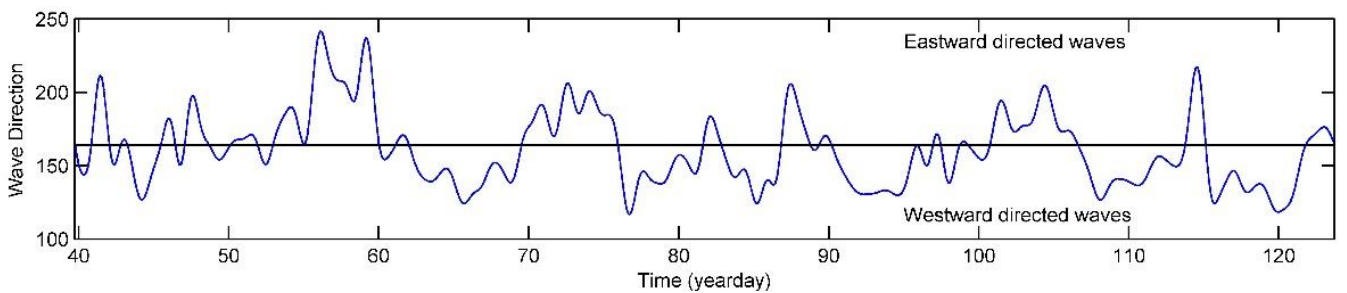

Figure 4.1: Time-series, during yeardays 40-123 in 2014, of a) wind stress (oceanographic notation), b) atmospheric pressure, and c) air temperature averaged from sites 1 and 8. Wave climate averaged from all 6 sites including d) significant wave height, e) peak (dotted) and mean (solid) wave period, and f) wave direction (oceanographic notation, waves come from). In a), north is oriented towards the top, and the coastline orientation is shown in black. 
a)

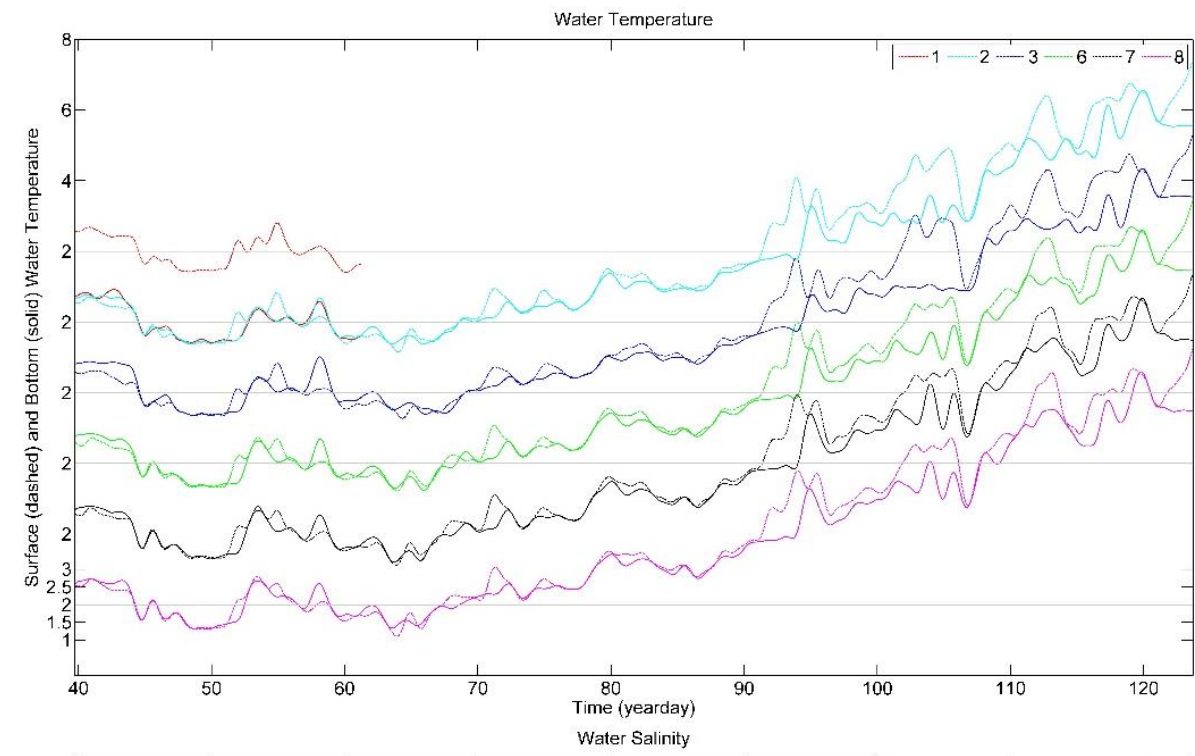

b)

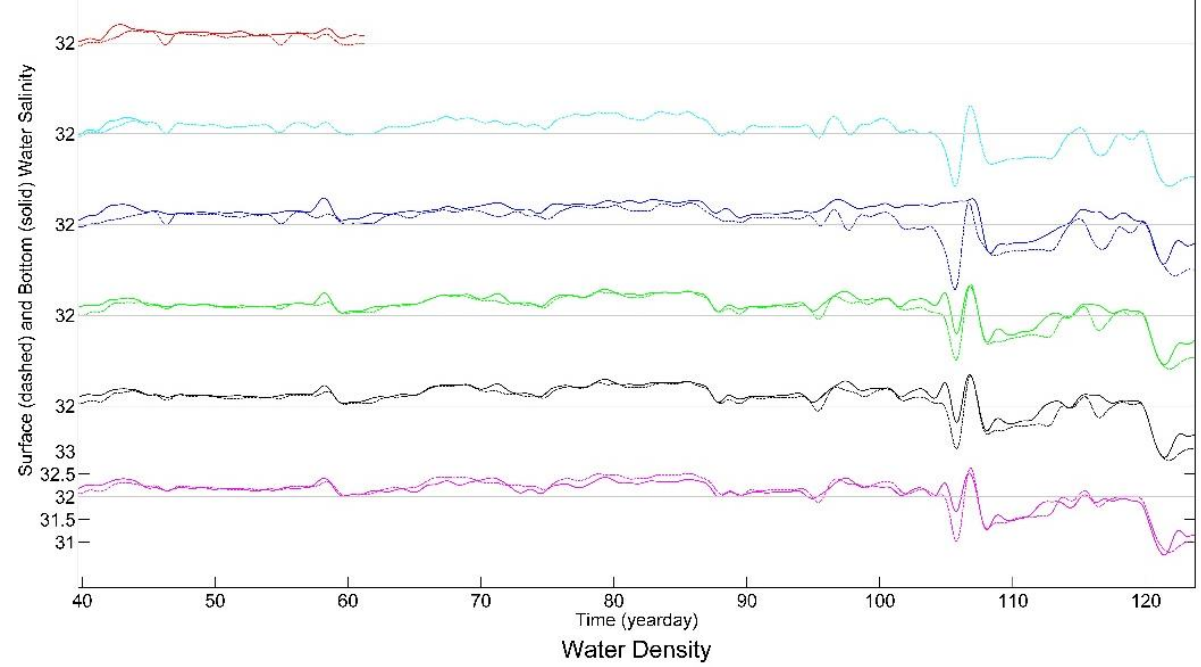

c)

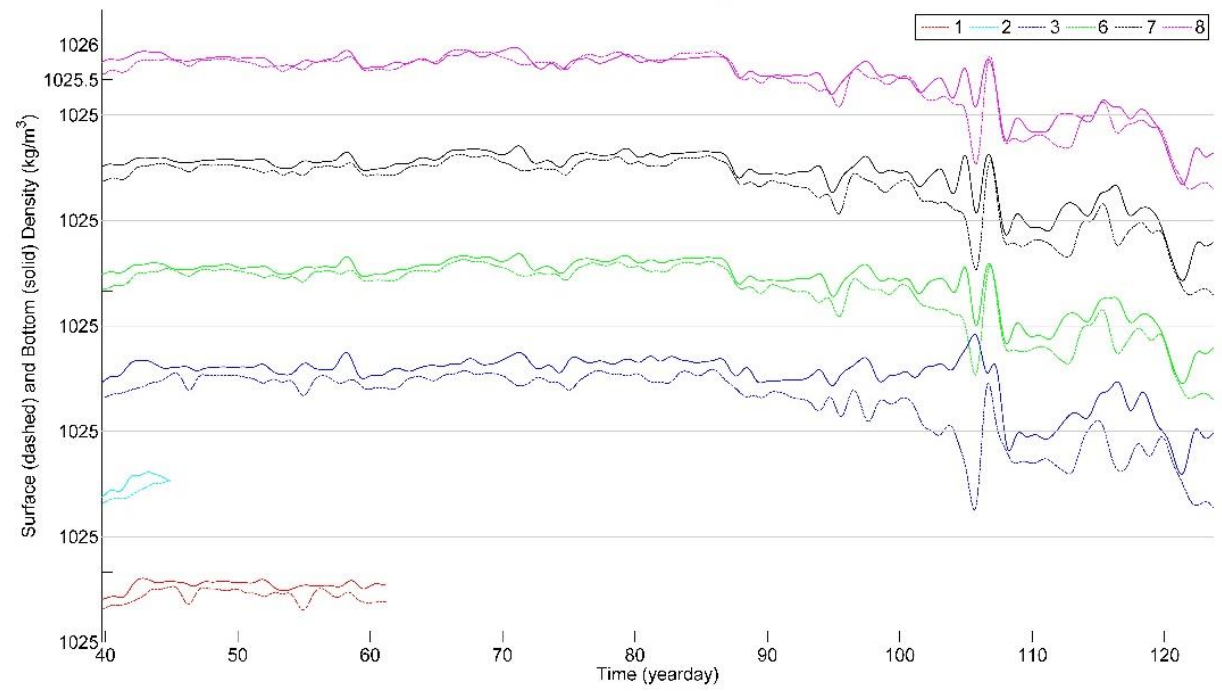

Figure 4.2: Surface (dashed) and bottom (solid) water properties at all 6 sites. a) Temperature $\left.\left({ }^{\circ} \mathrm{C}\right), \mathrm{b}\right)$ Salinity (ppt), and c) Density $\left(\mathrm{kg} / \mathrm{m}^{3}\right)$. 
a)

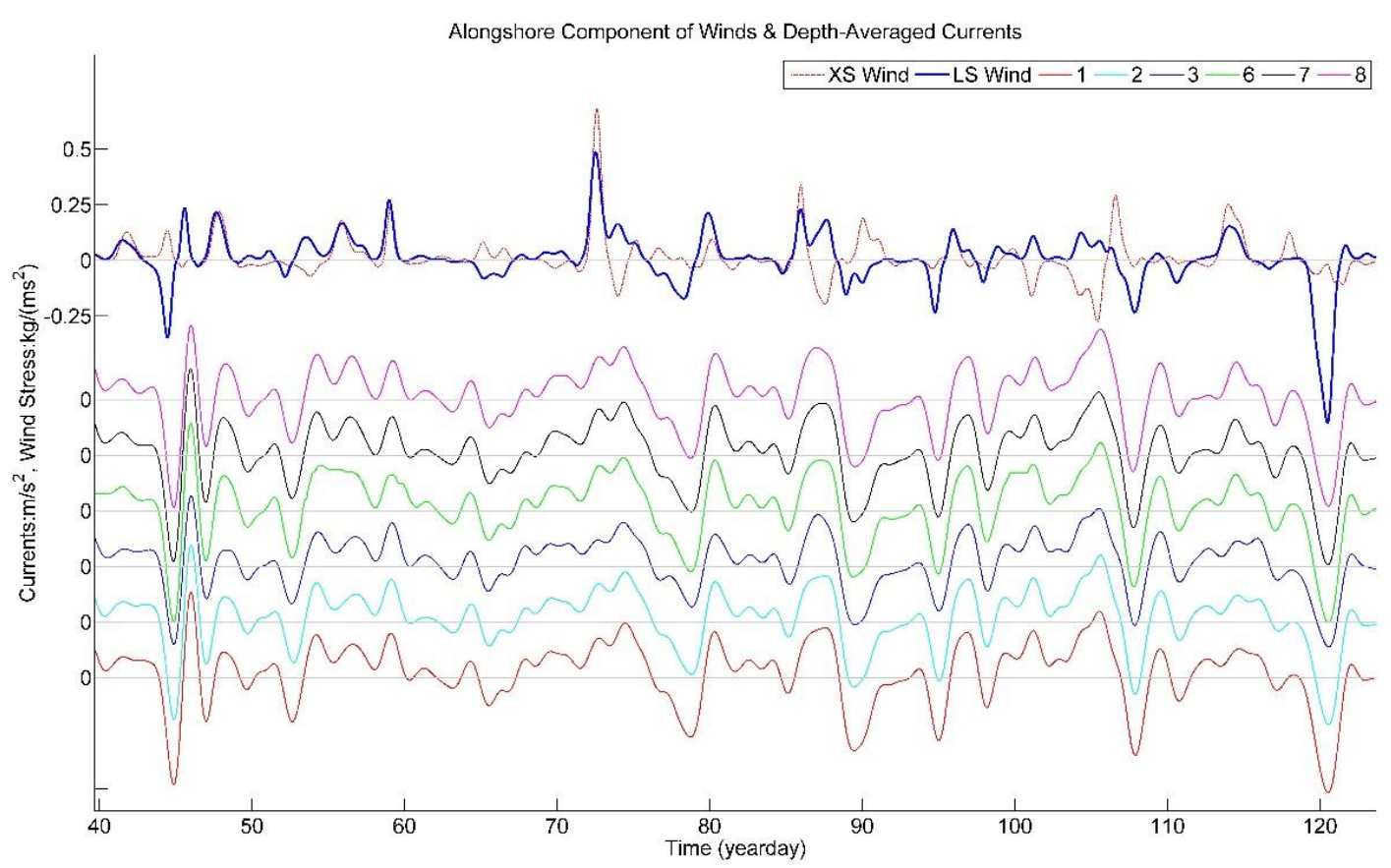

b)

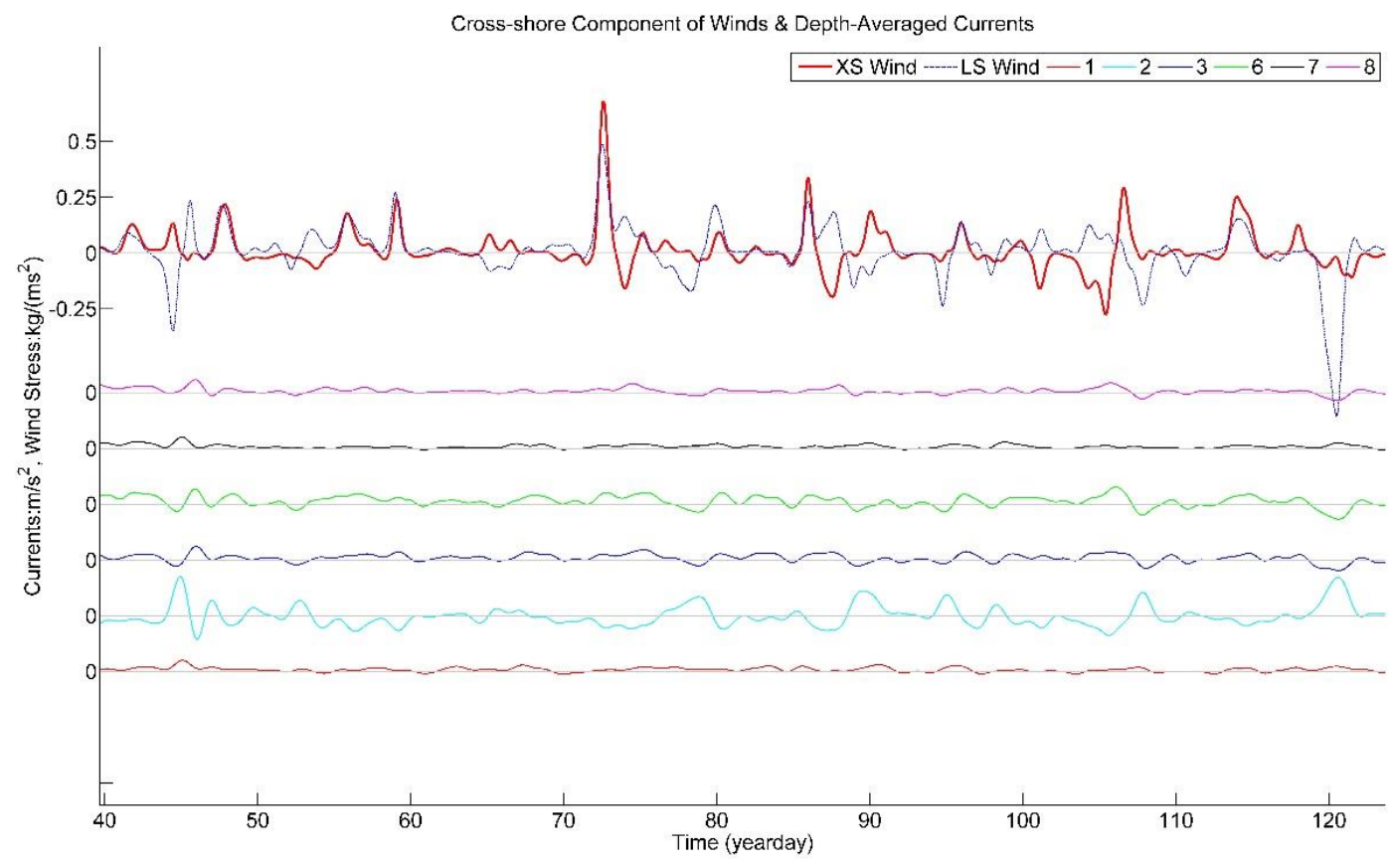

Figure 4.3: Time-series of depth-averaged, sub-tidal, a) alongshore (v) and b) crossshore (u), wind stress (bold, N/m) and currents $(\mathrm{m} / \mathrm{s})$. The scale shown for winds is equal to that of currents. 


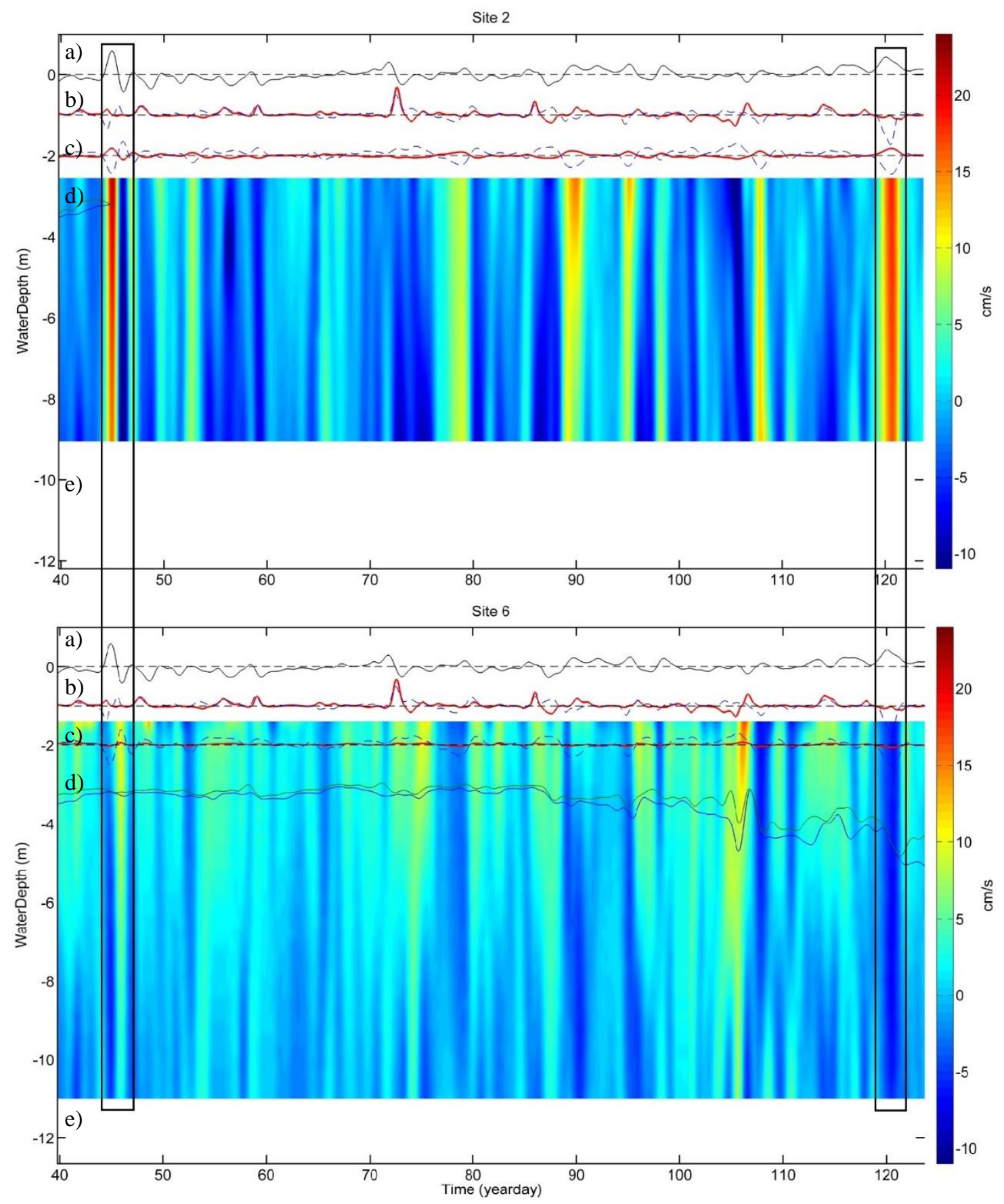

Figure 4.4: Time-series at site 2 (SFCR crest) and site 6 (SFCR trough) of a) sea level $(\mathrm{m}), \mathrm{b})$ alongshore (blue, dashed) and cross-shore (red, bold) wind stress $\left.\left(\mathrm{N} / \mathrm{m}^{2}\right), \mathrm{c}\right)$ alongshore (blue, dashed) and cross-shore (red, bold) depth-averaged current $(\mathrm{m} / \mathrm{s}), \mathrm{d}$ ) surface (green) and bottom (blue) density $\left(\mathrm{kg} / \mathrm{m}^{3}\right)$, and e) cross-shore current (color bar, $\mathrm{cm} / \mathrm{s}$ ) with depth (m). Black boxes highlight the nor'easter and tornado-associated storm discussed in section 4.1. 


\section{Chapter 5: Alongshore Momentum Balance Analysis}

The dominant drivers of flow and the dominant response of the ocean are examined using alongshore momentum balance analysis. Three locations, A, B and C (see Figure 3.1), have been selected for this analysis that are located halfway between sites 1 and 7, sites 1 and 8, and sites 7 and 8, respectively. The goal of this analysis is to quantitatively determine the influence of SFCRs on inner shelf circulation. The momentum balance equation is adopted from Lentz and Winant (1986) with the exclusion of the divergence of Reynolds stress, and the inclusion of the contribution of waves in bottom stress. The depth-averaged, alongshore momentum balance equation is,

$$
\frac{\partial \bar{v}}{\partial t}+f(\bar{u})+\bar{u} \frac{\partial \bar{v}}{\partial x}+\bar{v} \frac{\partial \bar{v}}{\partial y}+\frac{\tau_{b c w}}{\rho_{r} * h}=-\frac{1}{\rho_{r}} \frac{\partial P}{\partial y}+\frac{\tau_{s}}{\rho_{r} * h}
$$

$$
\text { LA } \quad \text { CA } \quad A A \quad \text { BS } \quad \text { PGF SS }
$$

where, $\bar{u}$ and $\bar{v}$ are cross-shore (x) and alongshore (y), depth-averaged velocity components, respectively; $f$ is the Coriolis parameter; $\tau_{b c w}$ is the current and wave combined bottom stress; $P$ is pressure, calculated as depth-averaged baroclinic pressure with SeaGauge pressure sensors and as barotropic surface pressure with tide gauges and atmospheric pressure (see section 5.1); and, $\tau_{s}$ is surface stress (i.e. wind stress). Finally, $\rho_{r}$ is a reference density $\left(=1025.4 \mathrm{~kg} / \mathrm{m}^{3}\right)$ and $h$ is water depth. The left hand side of the momentum balance equation is grouped as a response term, defined as current-dependent 
terms, and the right hand side of the equation is grouped as a force term, defined as current-independent terms (Kumar et al. 2013).

\subsection{Alongshore Momentum Balance Calculation}

The local acceleration (LA) was calculated through a first-order derivative of the alongshore current. We applied three equations,

$$
\begin{aligned}
& F^{\prime}(x)=\frac{F(x+1)-F(x)}{d x} \\
& F^{\prime}(x)=\frac{F(x+1)-F(x-1)}{2 d x} \\
& F^{\prime}(x)=\frac{F(x)-F(x-1)}{d x}
\end{aligned}
$$

a forward differencing scheme (to the start of each time series), a central differencing scheme (throughout the middle), and a backward differencing scheme (at the end), respectively.

The Coriolis acceleration (CA) is the product of the Coriolis parameter $(f=$ $2 \Omega \sin ($ latitude $\left.), \Omega=\frac{2 \pi}{86160} \mathrm{rad} / \mathrm{s}\right)$ and cross-shore currents.

The form of the $y$-dimensional, nonlinear advective acceleration equation (AA) is the standard equation,

$$
A A=\bar{u} \frac{\partial \bar{v}}{\partial x}+\bar{v} \frac{\partial \bar{v}}{\partial y}
$$

Given the one-dimensional site array, AA is calculated under the assumption that

alongshore (v) velocities are constant in the cross-shore direction which reduces $\bar{u} \frac{\partial \bar{v}}{\partial x}$ to zero. Another option would be to assume that alongshore (v) velocities reduce to zero at the coastal boundary. The two extremes were used in momentum balance calculation and the former assumption proved to better the balance and is used from here on. 
Wave and current combined bottom stress (BS) was calculated using Soulsby's (1997) method which accounts for the bottom stress-enhancing, nonlinear interaction of wave and current boundary layers. A data-base of thirteen theoretical models provided necessary fitting coefficients, the friction factor, and the drag coefficient. Bulk wave parameters were used to calculate maximum bottom orbital velocities following Wiberg and Sherwood (2008).

Pressure gradient force (PGF) was calculated two ways to provide a regional and local PGF. The regional, barotropic pressure gradient force $\left(P G F_{t g}\right)$ was calculated using tide gauge and atmospheric pressure data from two NOAA stations, Montauk, NY (Station ID: 8510560) and Sandy Hook, NJ (Station ID: 8531680) which span the length of Long Island. Since Sandy Hook, NJ lacked atmospheric pressure data, those from a nearby station, Robbins Reef, NJ (Station ID: 8530973), were used instead. The datum used from these stations is the station datum (STND), a fix based elevation reference. The regional, barotropic PGF $\left(P G F_{t g}\right)$, was calculated using the method of Harms and Winant (1994):

$$
\begin{gathered}
P_{S}=\rho_{r} g \eta \\
P G F_{t g}=\frac{1}{\rho_{r}} \frac{\partial(P s+P a)}{\partial y}
\end{gathered}
$$

where, $P G F_{t g}$ is the regional, tide gauge calculated pressure gradient force $\left(\mathrm{m} / \mathrm{s}^{2}\right), P s$ is barotropic pressure (in Pascal), $\eta$ is the sub-tidal water level measured from the tide gauge (m), and $P a$ is the atmospheric pressure (in Pascal).

Depth-averaged, baroclinic pressure gradients were estimated using the Seagauge pressure sensors from sites 1, 7, and 8 which span a region of $\sim 7 \mathrm{~km}$. Bottom pressures were converted to surface pressure through: 


$$
P_{s}=P_{b}-\rho_{m} g h
$$

where, $P_{s}$ is surface (barotropic) pressure, and $P_{b}$ is bottom pressure. $\rho_{m}$ is the mid-water column density $\left(\mathrm{kg} / \mathrm{m}^{3}\right)$, estimated from bottom and surface density values and an assumed linearly sloping density gradient with depth. In order to compensate for the Bernoulli effects that the pressure recorded at the sea bed, surface pressure was adjusted by subtracting the additional pressure due to the mean current over the sensor $\left(-\frac{K \rho_{b} \bar{v}^{2}}{2}\right.$ where $K=1.09$, and $\rho_{b}$ is the bottom density, see Muir 1978). Mid-water column pressure, $P_{m}$, was then calculated:

$$
P_{m}=P_{s}+\frac{\rho_{.25} g h}{2}
$$

where, $\rho_{.25}$ is the density of the top quarter of the water column, and $h$ is the depth of the location of pressure gradient calculation (i.e. halfway between two pressure sensors, sites $\mathrm{A}, \mathrm{B}$, and C). Because bottom pressures were measured on an uneven bathymetry, the surface pressure and the mid-water column pressures were averaged to obtain the depthaveraged values in order to accurately compare pressures at different sites.

$$
P_{d a}=\frac{P_{m}+P_{s}}{2}
$$

Finally, pressure gradient force was calculated:

$$
P G F_{s g}=\frac{1}{\rho_{r}} \frac{\partial P_{d a}}{\partial y}
$$

where, $P G F_{s g}$ is the local, Seagauge pressure sensor calculated pressure gradient force $\left(\mathrm{m} / \mathrm{s}^{2}\right)$. A ten day running mean was then removed from $\mathrm{PGF}_{\mathrm{sg}}$ to remove a gentle positive trend which extended from the start to end of the study period and may have resulted from tripod settling. 
Wind stress was estimated from two meteorological buoys, deployed at site 1 and site 8 , which were averaged to represent wind conditions across the entire field of study. Alongshore surface stress, $L S \tau_{s}$, is calculated using the formula of Large et al. (1995),

$$
L S \tau_{s}=\rho_{\text {air }} * C d *|U| * v
$$

where, $C d=\left(0.142+0.0764 * U+\frac{2.7}{U+10^{-6}}\right) * 10^{-3}$

where $\rho_{\text {air }}$ is air density, $C d$ is a drag coefficient which increases with wind speed, $U$ is the wind speed $(\mathrm{m} / \mathrm{s})$ at $10 \mathrm{~m}$ above the sea surface, and $v$ is the alongshore wind velocity. In a comparison of wind stress calculated through Large and Pond's (1981) formula, there was no marked difference, and the formula presented above was used for analysis.

\subsection{Alongshore Momentum Balance Results}

The time-series of momentum balance calculation is presented in Figures 5.1-5.3. Site A was calculated from averages of the gradients between sites 1 and 7; site B came from sites 1 and 8; and, and site $\mathrm{C}$ came from sites 7 and 8. Momentum balance term correlation coefficients and standard deviations are presented in Tables 5.1-5.4. In order to better assess our success in defining forces and responses, an ideal pressure gradient force was calculated which perfectly balances the momentum balance equation. The calculation used the five other terms of equation (1) to obtain the ideal pressure gradient force, $P G F_{i}$ :

$$
P G F_{i}=\frac{\tau_{s}}{\rho_{r^{* h}}}-\frac{\partial \bar{v}}{\partial t}-f(\bar{u})-\bar{u} \frac{\partial \bar{v}}{\partial x}-\bar{v} \frac{\partial \bar{v}}{\partial y}-\frac{\tau_{b c w}}{\rho_{r^{* h}}}
$$

To identify the optimal balance of momentum terms, three variations on the forcing (all including wind stress), and four variations on the response (all including bottom stress) were correlated to find the best representation of the alongshore dynamics 
(Table 5.4). Additionally, the standard deviation of the residual acceleration was used to identify which combination of terms left the smallest amount of uncertainty. In its full form, residual acceleration was calculated by,

$$
\text { residual }=-\frac{1}{\rho_{r}} \frac{\partial P}{\partial y}+\frac{\tau_{s}}{\rho_{r^{* h}}}-\frac{\partial \bar{v}}{\partial t}-f(\bar{u})-\bar{u} \frac{\partial \bar{v}}{\partial x}-\bar{v} \frac{\partial \bar{v}}{\partial y}-\frac{\tau_{b c w}}{\rho_{r^{* h}}}
$$

This is a rearrangement of equation (1) which subtracts the response from both sides of the equation.

Throughout all sites, wind stress was the primary driver of flow ( $\operatorname{std}=9.02 \times 10^{-6}$ $\left.\mathrm{m} / \mathrm{s}^{2}\right)$, and bottom stress was the primary response $\left(\mathrm{std}=4.12 \times 10^{-6} \mathrm{~m} / \mathrm{s}^{2}\right)$. Local acceleration played a significant role $\left(\mathrm{std}=2.60 \times 10^{-6} \mathrm{~m} / \mathrm{s}^{2}\right)$. The Coriolis acceleration was relatively small $\left(\mathrm{std}=0.79 \times 10^{-6} \mathrm{~m} / \mathrm{s}^{2}\right)$, but at site A it did contribute to a better balance of force and response. Advective acceleration at sites A and B were of a small magnitude $\left(\mathrm{std}=0.53 \times 10^{-6} \mathrm{~m} / \mathrm{s}^{2}\right)$. Advective acceleration was larger at site $\mathrm{C}\left(\mathrm{std}=1.85 \times 10^{-6} \mathrm{~m} / \mathrm{s}^{2}\right)$. In all three cases, AA did contribute to a higher force, response correlation and a lower residual acceleration standard deviation.

The inclusion of regional PGF as a forcing term never increased the correlation of force and response, however, in all three cases it lowered the standard deviation of the residual acceleration. Regional PGF was negatively correlated with wind stress $(\mathrm{r}=-0.86)$, and well correlated with the ideal PGF $(r=0.75)$. The most accurate representation of forcing across our site comes from wind stress and regional PGF. Local PGF was less successful in accurately representing the force, especially at site $\mathrm{C}$ where the small distance between Seagauge pressure sensors $(\partial y)$ dramatically increased the calculated local PGF. Subtracting regional PGF from local PGF was attempted to reveal the influence of SFCRs, but proved unsuccessful and is not presented here. 
Site A, B, and C were best balanced by a regional PGF and SS forcing with a BS, LA, and AA response (Table 5.4). 
Table 5.1 - Site A correlation coefficients ( $r=$ ) of alongshore momentum balance terms (equation 1). Column 1 contains standard deviations $\left(10^{-6} \mathrm{~m} / \mathrm{s}^{2}\right)$ in addition to variable name.

\begin{tabular}{|c|c|c|c|c|c|c|c|c|}
\hline Site A & PGF $_{\mathrm{tg}}$ & PGF $_{\mathrm{sg}}$ & PGF $_{\mathrm{i}}$ & $\mathrm{SS}$ & $\mathrm{LA}$ & $\mathrm{CA}$ & $\mathrm{AA}$ & $\mathrm{BS}$ \\
\hline PGF $_{\mathrm{tg}}, 3.47$ & 1 & 0.19 & 0.79 & -0.86 & -0.14 & 0.08 & -0.36 & -0.69 \\
\hline PGF $_{\mathrm{sg}}, 6.27$ & & 1 & 0.16 & -0.20 & -0.26 & -0.09 & 0.18 & -0.09 \\
\hline $\mathrm{PGF}_{\mathrm{i}}, 6.05$ & & & 1 & -0.88 & -0.06 & 0.21 & -0.32 & -0.47 \\
\hline $\mathrm{SS}, 9.10$ & & & & 1 & 0.36 & -0.10 & 0.36 & 0.73 \\
\hline $\mathrm{LA}, 2.62$ & & & & & 1 & 0.24 & -0.16 & 0.03 \\
\hline $\mathrm{CA}, 0.79$ & & & & & & 1 & -0.11 & -0.27 \\
\hline $\mathrm{AA}, 0.53$ & & & & & & & 1 & 0.36 \\
\hline $\mathrm{BS}, 3.73$ & & & & & & & & 1 \\
\hline
\end{tabular}


Table 5.2 - Site B correlation coefficients ( $r=$ ) of alongshore momentum balance terms (equation 1). Column 1 contains standard deviations $\left(10^{-6} \mathrm{~m} / \mathrm{s}^{2}\right)$ in addition to variable name.

\begin{tabular}{|c|c|c|c|c|c|c|c|c|}
\hline Site B & PGF $_{\mathrm{tg}}$ & PGF $_{\mathrm{sg}}$ & PGF $_{\mathrm{i}}$ & SS & LA & CA & AA & BS \\
\hline PGF $_{\mathrm{tg}}, 3.47$ & 1 & 0.54 & 0.72 & -0.86 & -0.14 & -0.43 & -0.29 & -0.67 \\
\hline PGF $_{\mathrm{sg}}, 3.31$ & & 1 & 0.41 & -0.45 & -0.02 & -0.25 & -0.01 & -0.41 \\
\hline PGF $_{\mathrm{i}}, 5.60$ & & & 1 & -0.80 & -0.09 & -0.10 & -0.32 & -0.26 \\
\hline $\mathrm{SS}, 8.97$ & & & & 1 & 0.36 & 0.41 & 0.38 & 0.70 \\
\hline $\mathrm{LA}, 2.59$ & & & & & 1 & 0.17 & -0.13 & 0.01 \\
\hline $\mathrm{CA}, 0.77$ & & & & & & 1 & 0.11 & 0.43 \\
\hline $\mathrm{AA}, 0.53$ & & & & & & & 1 & 0.30 \\
\hline $\mathrm{BS}, 4.33$ & & & & & & & & 1 \\
\hline
\end{tabular}


Table 5.3 - Site C correlation coefficients ( $r=$ ) of alongshore momentum balance terms (equation 1). Column 1 contains standard deviations $\left(10^{-6} \mathrm{~m} / \mathrm{s}^{2}\right)$ in addition to variable name.

\begin{tabular}{|c|c|c|c|c|c|c|c|c|}
\hline Site C & PGF $_{\mathrm{tg}}$ & PGF $_{\mathrm{sg}}$ & PGF $_{\mathrm{i}}$ & SS & LA & CA & AA & BS \\
\hline PGF $_{\mathrm{tg}}, 3.47$ & 1 & 0.17 & 0.73 & -0.86 & -0.14 & -0.46 & 0.00 & -0.68 \\
\hline PGF $_{\mathrm{sg}}, 23.70$ & & 1 & 0.21 & -0.11 & 0.27 & 0.11 & 0.16 & -0.18 \\
\hline PGF $_{\mathrm{i}}, 5.66$ & & & 1 & -0.77 & -0.07 & -0.16 & 0.16 & -0.30 \\
\hline SS, 9.00 & & & & 1 & 0.36 & 0.48 & 0.12 & 0.72 \\
\hline LA, 2.60 & & & & & 1 & 0.18 & 0.00 & 0.02 \\
\hline $\mathrm{CA}, 0.80$ & & & & & & 1 & 0.03 & 0.49 \\
\hline $\mathrm{AA}, 1.85$ & & & & & & & 1 & 0.02 \\
\hline $\mathrm{BS}, 4.29$ & & & & & & & & 1 \\
\hline
\end{tabular}


Table 5.4 - Correlation coefficients ( $r=$ ) of alongshore momentum balance Force vs. Response, followed by the standard deviations $\left(10^{-6} \mathrm{~m} / \mathrm{s}^{2}\right)$ of residual acceleration (equation 10). Bold cells indicate the best correlation and lowest standard deviation in each respective row. Red cells indicate the combination of force terms and response terms which best balance equation 1 at each site.

\begin{tabular}{|c|c|c|c|c|}
\hline Correlation & \multicolumn{4}{|c|}{ Response } \\
\hline Force & BS & Force & BS & Force \\
\hline Site A: SS & $0.73,6.85$ & Site A: SS & $0.73,6.85$ & Site A: SS \\
\hline Site A: $\mathrm{SS}+\mathrm{PGF}_{\mathrm{sg}}$ & $0.67,8.12$ & $\begin{array}{c}\text { Site A: } \\
\text { SS+PGF }_{\text {sg }}\end{array}$ & $0.67,8.12$ & $\begin{array}{c}\text { Site A: } \\
\text { SS+PGF }_{\mathrm{sg}}\end{array}$ \\
\hline Site A: $\mathrm{SS}+\mathrm{PGF}_{\mathrm{tg}}$ & $0.67,4.73$ & $\begin{array}{c}\text { Site A: } \\
\text { SS+PGF }_{\mathrm{tg}}\end{array}$ & $0.67,4.73$ & Site A: $\mathrm{SS}+\mathrm{PGF}_{\mathrm{tg}}$ \\
\hline Site B: SS & $0.70,6.69$ & Site B: SS & $0.70,6.69$ & Site B: SS \\
\hline Site B: SS+PGF $\mathrm{sg}$ & $0.69,6.05$ & $\begin{array}{c}\text { Site B: } \\
\text { SS+PGF }_{\mathrm{sg}}\end{array}$ & $0.69,6.05$ & Site $\mathrm{B}: \mathrm{SS}+\mathrm{PGF}_{\mathrm{sg}}$ \\
\hline Site B: $S S+P G F_{t g}$ & $0.64,4.81$ & $\begin{array}{c}\text { Site B: } \\
\text { SS+PGF }_{\mathrm{tg}}\end{array}$ & $0.64,4.81$ & Site B: SS+PGF \\
\hline Site C: SS & $0.72,6.62$ & Site C: SS & $0.72,6.62$ & Site C: SS \\
\hline Site $\mathrm{C}: \mathrm{SS}+\mathrm{PGF}_{\mathrm{sg}}$ & $0.11,24.27$ & $\begin{array}{c}\text { Site C: } \\
\mathrm{SS}_{\mathrm{PGF}} \mathrm{Pg}\end{array}$ & $0.11,24.27$ & Site $\mathrm{C}: \mathrm{SS}+\mathrm{PGF}_{\mathrm{sg}}$ \\
\hline Site C: $\mathrm{SS}+\mathrm{PGF}_{\mathrm{tg}}$ & $0.66,4.71$ & $\begin{array}{c}\text { Site C: } \\
\text { SS+PGF }_{\mathrm{tg}}\end{array}$ & $0.66,4.71$ & Site C: $\mathrm{SS}+\mathrm{PGF}_{\mathrm{tg}}$ \\
\hline
\end{tabular}




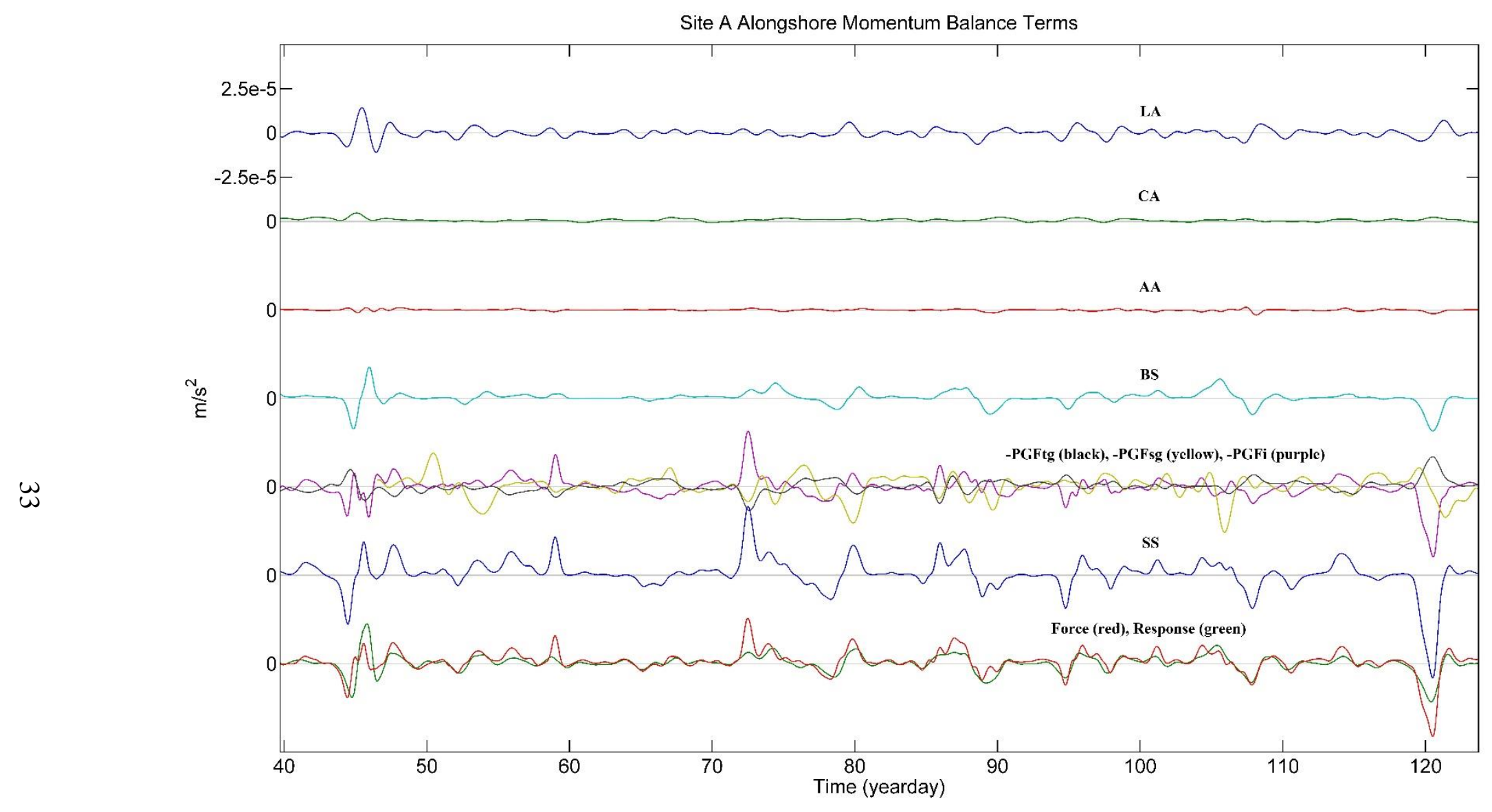

Figure 5.1: Time-series of sub-tidal, depth-averaged momentum balance terms ( $\mathrm{m} / \mathrm{s}^{2}$, equation 1): local acceleration (LA, blue), Coriolis acceleration (CA, green), advective acceleration (AA, red), wave-current combined bottom stress (BS, cyan), regional pressure gradient force $\left(-\mathrm{PGF}_{\mathrm{tg}}\right.$, black), local pressure gradient force (-PGF $\mathrm{sg}$, gold), ideal pressure gradient force (-PGF $\mathrm{i}_{\mathrm{i}}$, gray), wind stress (SS, blue), atmospheric force (red), and ocean response (green), for Site A (see Figure 3.1). 


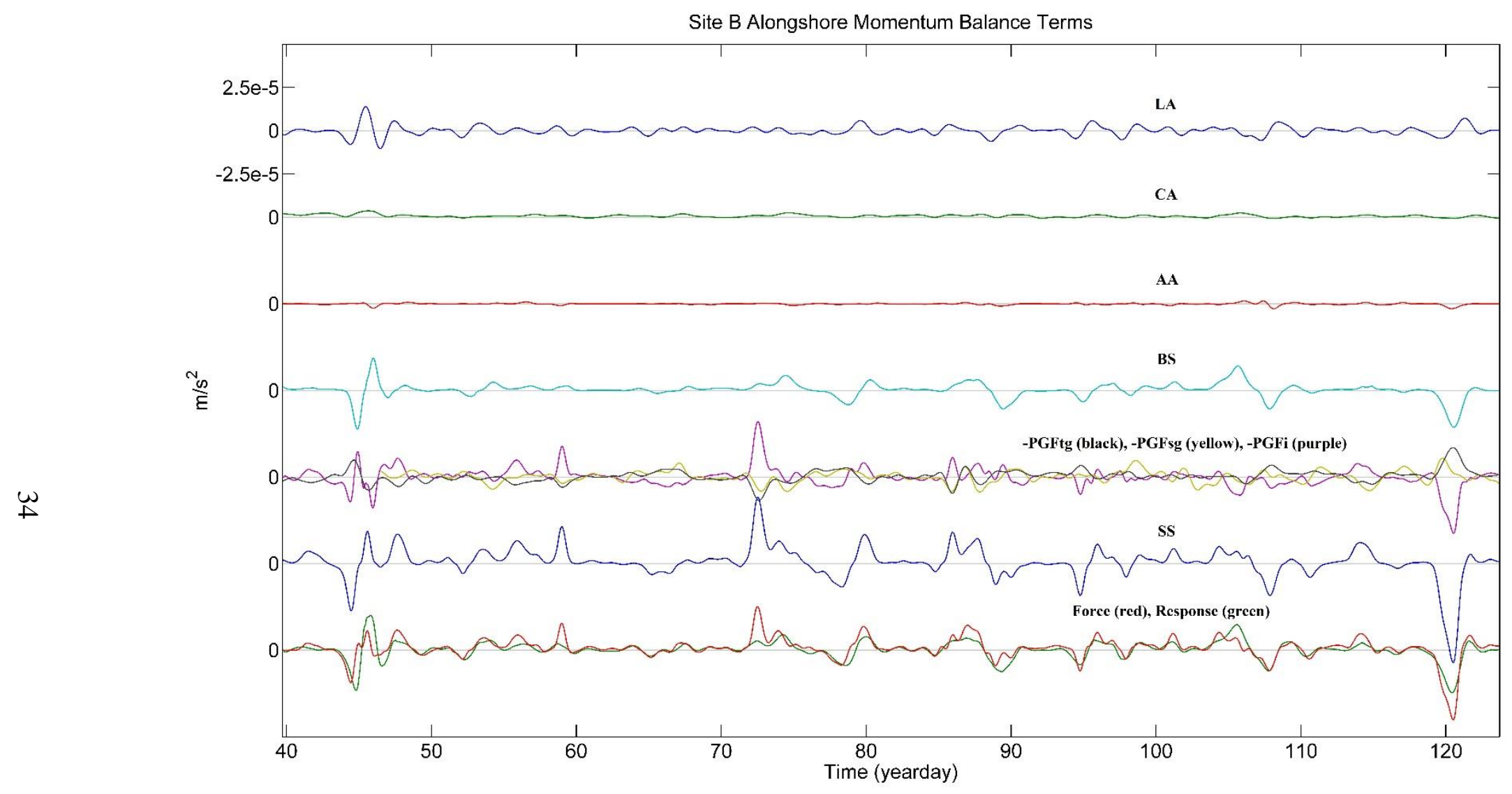

Figure 5.2: Time-series of sub-tidal, depth-averaged momentum balance terms ( $\mathrm{m} / \mathrm{s}^{2}$, equation 1$)$ : local acceleration (LA, blue), Coriolis acceleration (CA, green), advective acceleration (AA, red), wave-current combined bottom stress (BS, cyan), regional pressure gradient force $\left(-\mathrm{PGF}_{\mathrm{tg}}\right.$, black), local pressure gradient force $\left(-\mathrm{PGF}_{\mathrm{sg}}\right.$, gold), ideal pressure gradient force (-PGF ${ }_{\mathrm{i}}$, gray), wind stress (SS, blue), atmospheric force (red), and ocean response (green), for Site B (see Figure 3.1). 
Site C Alongshore Momentum Balance Terms

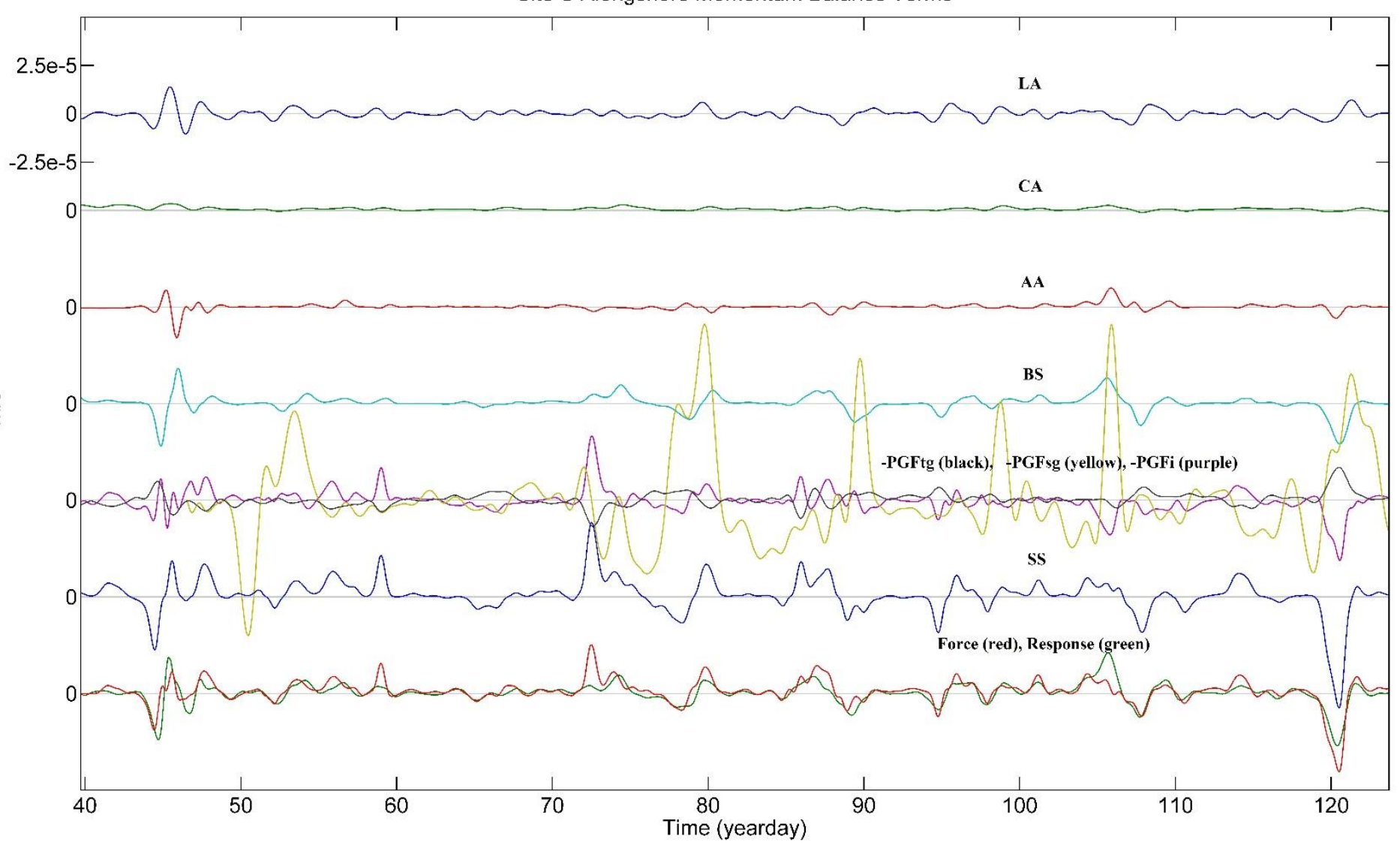

Figure 5.3: Time-series of sub-tidal, depth-averaged momentum balance terms ( $\mathrm{m} / \mathrm{s}^{2}$, equation 1): local acceleration (LA, blue), Coriolis acceleration (CA, green), advective acceleration (AA, red), wave-current combined bottom stress (BS, cyan), regional pressure gradient force $\left(-\mathrm{PGF}_{\mathrm{tg}}\right.$, black), local pressure gradient force (-PGF $\mathrm{sg}$, gold), ideal pressure gradient force (-PGF $\mathrm{i}_{\mathrm{i}}$, gray), wind stress (SS, blue), atmospheric force (red), and ocean response (green), for Site C (see Figure 3.1). 


\section{Chapter 6: Discussion}

\subsection{Alongshore Momentum Balance Analysis}

The negative correlation of regional PGF with wind stress (Tables 5.1-5.3) indicates that the regional PGF was set up by wind-induced, current convergence and divergence zones. Cross-correlation revealed regional PGF to lag 3 hours behind wind stress, which further supports the idea of wind set up pressure gradients. Additionally, the regional PGF's strong correlation with the ideal PGF show that regional PGF calculation was reasonable and helped to balance the momentum balance equation.

Although local acceleration was the second smallest term, it was significant in balancing the force and response. Cross-correlation of wind stress and local acceleration found that local acceleration peaked 8 hours ahead of wind stress peaks, and thus aligned best with wind stress directional changes which is the moment when accelerations should be strongest.

Bottom stress was the largest response term, a common finding of inner shelf studies. Cross-correlation of wind stress and bottom stress revealed bottom stress to lag 7 hours behind wind stress which represents the time it takes for wind stress effects to fully propagate from the water column surface to bottom. In the momentum balance equation, this lag is accounted for by local acceleration.

The significance of advective acceleration provides two insights into the alongshore dynamics. First, alongshore momentum balance analyses along straight coastlines with unperturbed bathymetry have never found advective acceleration to be 
important. This is the case because in a general sense advective acceleration arises from geometric changes of the boundaries of flow. Contrarily, the $0.5 \mathrm{~m}$ depth variation along our one-dimensional transect is very small, yet is playing a role in the force response dynamics. This suggests that advective acceleration should be considered even over seemingly smooth bathymetry. Though, the large-scale bathymetry of our region, which has alongshore depth variations of up to $10 \mathrm{~m}$ due to SFCRs, could be influencing the circulation of our study site.

Second, site C (Figure 5.3) is located on the steepest slope of an SFCR (see Figure 3.1). The advective acceleration's significance and magnitude are stronger at site $\mathrm{C}$ than at sites A and B. This indicates that currents are accelerated most at the steep slope between an SFCR crest a trough, a result previously modeled by Warner et al. (2014). The local PGF modeled in Warner et al. (2014) showed a set down of the water level at SFCR crests and a setup of the water level at SFCR troughs which balance the advective accelerations in steady-state scenarios. Although we were unsuccessful in calculating local PGF, the agreeing advective acceleration distribution suggests that the modeled local PGF existed during the time of our study.

The best calculation of force versus response resulted from averaging the response from sites $\mathrm{A}, \mathrm{B}$, and $\mathrm{C}$ and comparing that to the regional forcing. This resulted in a correlation of $\mathrm{r}=0.81$, and a residual acceleration standard deviation of $3.71 \times 10^{-6}$ $\mathrm{m} / \mathrm{s}^{2}$ (Figure 6.1). This method likely produced the best results because the regional forcing, which came from wide spread (>180 km) tide gauges and wind stations $(>7 \mathrm{~km})$, should drive a flow which is typical along the entire inner shelf in that area. Therefore, averaging hydrodynamic response over a wavelength of SFCR allows for an indirect 
inclusion of the turbulence and boundary condition that the rhythmic topography imposes on the currents (Garvine 2004).

The momentum balance calculation was far from perfect, seen clearly in the residual acceleration plot of figure 6.1 where large spikes of error occur throughout. This error is most associated with alongshore wind stress ( $\mathrm{r}=0.52)$, especially in the eastward, alongshore direction, and during rapid changes in wind. In the spikes of error, it seems the hydrodynamic response is unable to "catch up" on such events as yearday 59 and 73. In other words, the momentum imparted by the wind is not fully received by the ocean. Local acceleration, i.e. the inertial term, is meant to account for the delay of transfer of momentum to the whole water column, but it does not fully capture this, especially on day 86 where major winds and rapid wind shifts should have forced a strong local acceleration that we did not see in our calculation (see Figures 5.1-5.3). Turbulence and shear stresses within the water column have the potential to account for seemingly lost momentum. We know from figure 4.4 that depth-averaging currents is an oversimplification because there is a certain degree of irregularity in flows with depth.

\subsection{Current Veering over SFCRs}

The current veering recognized in section 4.2 has been hypothesized to result from frictional torques and mass conservation (Trowbridge 1995, Warner et al., 2014, Ribas et al. 2015). Bottom stress standard deviations at shallow ( 12 m) water depths $\left(\mathrm{std}=3.49 \times 10^{-6} \mathrm{~m} / \mathrm{s}^{2}\right)$ are larger than those of the deeper $(\sim 16 \mathrm{~m}$ depth $)$ water at Site 3 $\left(\mathrm{std}=2.79 \times 10^{-6} \mathrm{~m} / \mathrm{s}^{2}\right)$. This cross-shore variation of bottom stress has the potential to unevenly affect alongshore currents. 
To explain, imagine a westward flowing volume of water approaching the upcurrent oriented SFCR crest (Figure $6.2 \mathrm{~b}$ ). Because the ridges are oriented $30^{\circ}$ clockwise from the coast, the most offshore component of the current will reach the ridge first. As a result, the offshore component will feel a stronger bottom stress and slow down in comparison to the onshore component. This will cause an offshore veering, similar to wave refraction. Now, take the opposite, eastward flowing current with a down-current oriented SFCR (Figure 6.2a). The most onshore component of this current will reach the ridge first, increasing the bottom stress, and causing the more onshore component to slow down first. The offshore component will begin to catch up, and the current will veer onshore.

Additionally, a cross-shore pressure gradient created by a cross-shore gradient of alongshore advective accelerations has been modelled as a potential mechanism of current veering (Warner et al. 2014). In other words, in alongshore flows, the first part of the water parcel to reach the crest will accelerate due to shallowing water. This induces a setdown of water level. The part of the water parcel which has not yet reached shallow water will not induce a setdown of the water level. The result is a cross-shore PGF which further drives current veering. Our alongshore momentum balance could not resolve cross-shore PGF, however, the general agreement between our alongshore observations and Warner et al.'s (2014) model suggest that their result is accurate.

From a bird's eye view, the streamline can be seen to follow along a contour line, always rotating clockwise when moving up-slope and rotating counter-clockwise when moving down-slope. Large scale tendencies for currents to follow bathymetric contour lines has been observed in other cases of inner shelf current analysis, along coastline 
orientations due to continuity effects (Kumar et al. 2013) and along small scale ripple orientations due to bottom roughness (Madsen et al. 2010).

In summary, the hydrodynamic force is best described as a combination of wind stress and pressure gradient force. The response of the flow is best described by bottom stress, local acceleration, and advective acceleration. A time lag of depth-averaged current to forcing was 9 hours, a result that is consistent with past inner shelf studies which have found a flow lag of 2-11 hours for depths $4 \mathrm{~m}$ to $26 \mathrm{~m}$ (Lentz et al. 1999). In cross-correlating force and response, the time lag is almost non-existent, meaning the local acceleration plays a vital role in balancing our momentum balance. A simple order of operations of the inner shelf dynamics can be summarized in the following manner. Wind blows on the ocean surface which drives current acceleration in the same direction. As currents flow towards areas unaffected by the local wind or constrained by boundaries, current convergence takes place and a sea surface setup drives a pressure gradient force in opposition of the wind stress. Simultaneously, the momentum imparted by wind stress on the water surface propagates downwards through the water column as a surface boundary layer. As the currents interact with the sea bed, turbulence-induced bottom stress begins to take effect and propagates upwards through the water column as a bottom boundary layer, overlapping with the surface boundary layer. The sea bed plays an additional role as fluctuations in morphology induce Bernoulli-like effects of advective acceleration. Ultimately, the wind-induced bottom stress and pressure gradients build and reduce the acceleration until a steady-state flow is achieved or until the wind patterns change. 
The above analysis successfully balanced the alongshore momentum balance equation on the inner shelf over SFCRs. It did not, however, fully capture the influence of SFCRs on inner shelf circulation. Although bottom pressure values from three Seagauge pressure sensors were well correlated, they inaccurately described the pressure gradient in the region, possibly due to uneven drifting and tripod settling (Lentz and Raubenheimer 1999). Bottom pressure values recorded similar signals, which showed a non-strict correlation with downwelling favorable winds, onshore winds, and high significant wave heights which holds the potential for wave setup (not presented here). From Warner et al. (2014), we expected to see a setup of water above SFCR troughs and setdown of water above SFCR crests, but regional pressure fluctuations may have masked this expected signal, or the non-steady state conditions may not have allowed for full development of this expected signal Additionally, though we did have one offshore site to aid in assessing the cross-shore variations in bottom stress, a more focused positioning of cross-shore sensors could potentially aid in quantifying the frictional torque affecting the current. SFCR influence on inner shelf circulation is truly a three-dimensional problem and therefore could be fully revealed with a parallelogram grid of 9 sites spanning one wavelength of an SFCR. This would allow for alongshore and cross-shore momentum balance analysis. Pressure observations at the 9 sites would require better accuracy, possibly attainable through burying the sensor. 


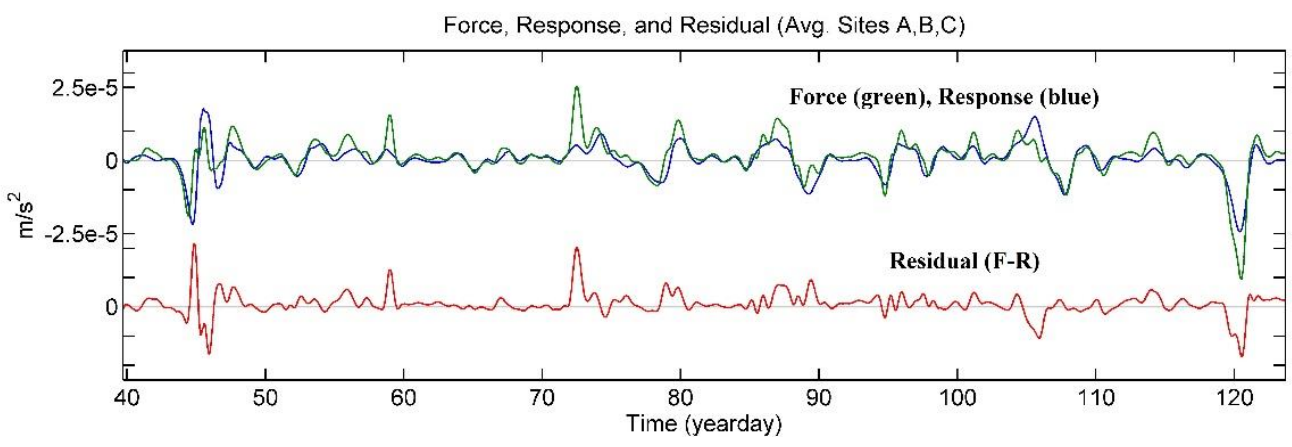

Figure 6.1: Time-series of sub-tidal, depth-averaged momentum balance force (green) and response (blue) $\left(\mathrm{m} / \mathrm{s}^{2}\right.$, equation 1$)$, and residual acceleration (red) $\left(\mathrm{m} / \mathrm{s}^{2}\right.$, equation 14$)$. Time-series are an average of the best balance of momentum terms at sites A, B, and C. 
a)
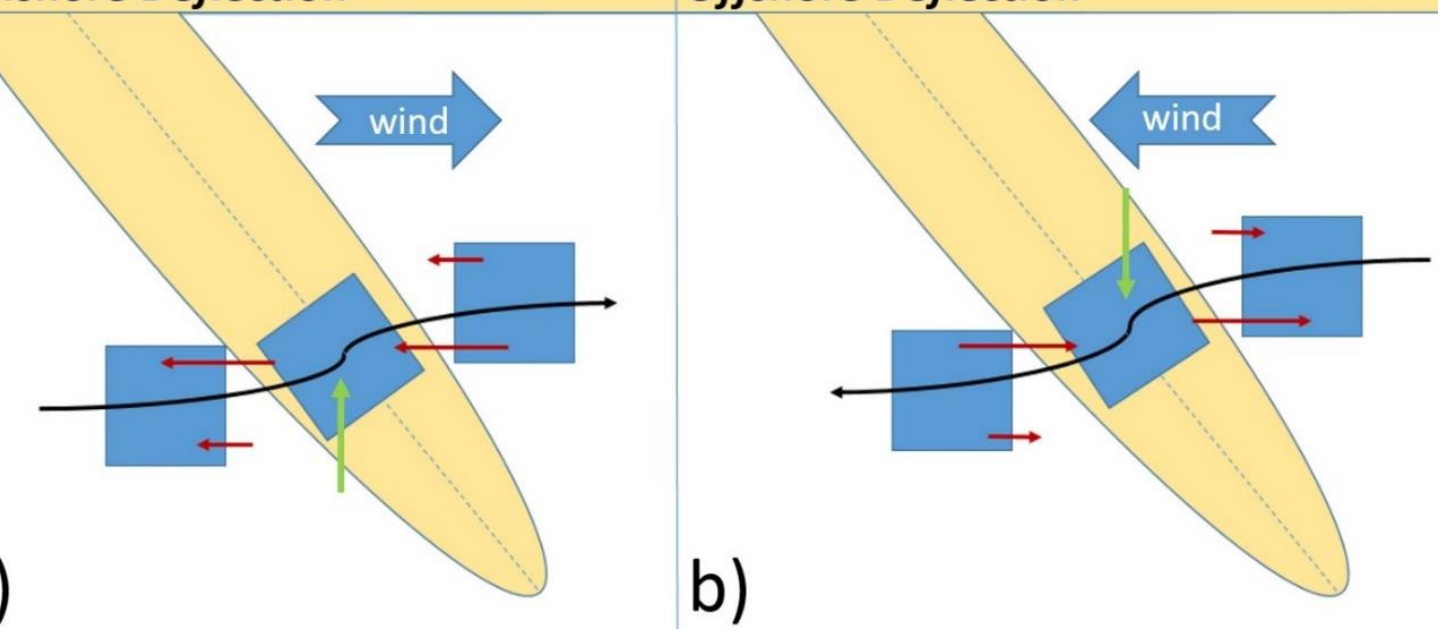

Figure 6.2: Schematic showing the potential_mechanisms of mass conservation and frictional torque induced current deflection over a ridge crest, plan-view. a) Onshore deflection b) Offshore deflection. Red arrows represent the magnitude of bottom stress; green arrows represent pressure gradient force; and, black arrows represent the current streamline of a water parcel (blue box). The coast is represented as the horizontal sand color at the top of the diagram. SFCRs are represented as sand colored ellipses oriented obliquely from the coast. 


\section{Chapter 7: Summary and Conclusions}

Inner shelf oceanographic ( 12 m depth) and meteorological observations were made during an 83 day field study beginning in February 2014 off of Fire Island, NY. The area is recognized for its large bathymetric features, shoreface-connected ridges (SFCRs), which can be found worldwide. SFCRs have been known to modify circulation in a way which contributes to their growth.

During our study, two major storms, a nor'easter on February $13^{\text {th }}$ and a storm on April $30^{\text {th }}$, forced currents which most clearly demonstrated the SFCR-modified circulation. Given SFCRs pointing up-current, alongshore currents veer offshore when travelling from trough to crest, and veer onshore when travelling from crest to trough. The offshore veering at SFCR crests causes current convergence and thus sediment deposition on ridge crests, a SFCR maintenance mechanism (Trowbridge 1995). Given SFCRs pointing down-current, alongshore currents veer onshore when travelling from trough to crest, and veer offshore when travelling from crest to trough. The onshore veering at SFCR crests causes current divergence and thus sediment erosion on ridge crests, a SFCR deconstructive mechanism (Warner et al. 2014).

Depth-averaged, sub-tidal alongshore momentum balance analysis over SFCRs was performed with moderate success and we believe our results apply to other regions with SFCRs (e.g., US Atlantic Coast, Brazilian shelf). Wind stress was the dominant driver of flow, and also contributed to the setup of a regional pressure gradient force, with the two combining as the forcing during our study. The pressure gradient setup 
lagged 3 hours behind wind stress. The response of flow primarily existed as bottom stress, with local acceleration filling the inertial gap between the forcing and bottom stress. Advective acceleration positively contributed to the balance, though was of small magnitude. Bottom stress and wind stress correlated well (r=0.72) and bottom stress lagged 7 hours behind wind stress.

SFCRs were recognized to significantly impact alongshore dynamics at Site A through advective acceleration, arising from alongshore variations of depth. Generally, alongshore currents spacially accelerated from SFCR trough to crest, and did not accelerate from SFCR crest to trough. The significance of observed acceleration due to shallowing agrees with modelled SFCR-related dynamics (Warner et al. 2014). Our alongshore observational agreement with Warner et al. (2014) suggests, but does not verify, that the recognition of cross-shore pressure gradient-induced current veering is accurate.

A second cause of current veering has been hypothesized as a cross-shore variation in bottom stress (i.e. frictionally) induced current veering. This study recognized a cross-shore variation in bottom stress which has the potential to induce veering, but a lack of data withheld further quantitative analysis.

Consequently, future observational research on the influence of SFCRs on inner shelf circulation should address both the 1) alongshore momentum balance, and 2) crossshore momentum balance, over a full SFCR wavelength. Research should also 3) aim to accurately resolve local pressure gradients. 


\section{References}

Armstrong, Brandy N., John C. Warner, Jeffrey H. List, Marinna A. Martini, Ellyn T. Montgomery, Peter Traykovski, and George Voulgaris. Coastal Change Processes Project data report for oceanographic observations near Fire Island, New York, February through May 2014. No. 2015-1033. US Geological Survey, 2015.

Austin, Jay A., and Steven J. Lentz. "The Inner Shelf Response to Wind-Driven Upwelling and Downwelling*." Journal of Physical Oceanography 32, no. 7 (2002): 2171-93.

Beardsley, Robert C., and Bradford Butman. "Circulation on the New England continental shelf: response to strong winter storms." Geophysical Research Letters 1.4 (1974): 181-184.

Beardsley, R. C., and C. D. Winant. "On the mean circulation in the Mid-Atlantic Bight." Journal of Physical Oceanography 9.3 (1979): 612-619.

Calvete, D., A. Falqués, H. E. De Swart, and M. Walgreen. "Modeling the Formation of Shoreface-Connected Sand Ridges on Storm-Dominated Inner Shelves." Journal of Fluid Mechanics 441 (2001): 169-93.

Calvete, D., M. Walgreen, H. E. De Swart, and A. Falqués. "A model for sand ridges on the shelf: Effect of tidal and steady currents." Journal of geophysical research 106.C5 (2001): 9311-9325.

Caston, V. N. D. “Linear Sand Banks In The Southern North Sea.” Sedimentology 18 (1972): 63-78.

Chapman, David C., and Robert C. Beardsley. "On the origin of shelf water in the Middle Atlantic Bight." Journal of Physical Oceanography 19.3 (1989): 384-391.

Churchill, J. H. "Properties of flow within the coastal boundary layer off Long Island, New York." Journal of physical oceanography 15.7 (1985): 898-916.

Csanady, G. T. "Mean circulation in shallow seas." Journal of Geophysical Research 81.30 (1976): 5389-5399.

Csanady, G. T. "The arrested topographic wave." Journal of Physical Oceanography 8.1 (1978): 47-62. 
Dragos, Paul, and David G. Aubrey. "Atlantic Shelf Sand Ridge Study: Physical Oceanography and Sediment Dynamics Data Report.” Woods Hole Oceanographic Institution, 1990.

Falqués, A., D. Calvete, H. E. De Swart, and N. Dodd. "Morphodynamics of Shoreface Connected Ridges.” Coastal Engineering Proceedings 1, no. 26 (1998).

Fewings, Melanie R., and Steven J. Lentz. "Momentum Balances on the Inner Continental Shelf at Martha's Vineyard Coastal Observatory." Journal of Geophysical Research 115, no. C12 (December 9, 2010).

Figueiredo, Alberto G., John E. Sanders, and Donald JP Swift. "Storm-graded layers on inner continental shelves: examples from southern Brazil and the Atlantic coast of the central United States." Sedimentary Geology 31.3 (1982): 171-190.

Flint, Richard Foster. "Glacial and Quaternary Geology." John Wiley and Sons. New York (1971): 892.

Foster, David S., B. Ann Swift, and William C. Schwab. Stratigraphic framework maps of the nearshore area of southern Long Island from Fire Island to Montauk Point, New York. No. 99-559. 1999.

Garnier, R., D. Calvete, A. Falques, and M. Caballeria. "Generation and Nonlinear Evolution of Shore-Oblique/transverse Sand Bars." Journal of Fluid Mechanics 567 (November 2006): 327.

Garvine, Richard W. "The Vertical Structure and Subtidal Dynamics of the Inner Shelf off New Jersey." Journal of Marine Research 62, no. 3 (2004): 337-71.

Gutierrez, Benjamin T., George Voulgaris, and Paul A. Work. "Cross-Shore Variation of Wind-Driven Flows on the Inner Shelf in Long Bay, South Carolina, United States." Journal of Geophysical Research 111, no. C3 (2006).

Han, G. C., and D. A. Mayer (1981), Current structure on the Long Island inner shelf, Journal of Geophysical Research 86(C5), 4205-4214

Hapke, Cheryl J., Erika E. Lentz, Paul T. Gayes, Clayton A. McCoy, Rachel Hehre, William C. Schwab, and S. Jeffress Williams. "A Review of Sediment Budget Imbalances along Fire Island, New York: Can Nearshore Geologic Framework and Patterns of Shoreline Change Explain the Deficit?" Journal of Coastal Research 263 (May 2010): 510-22.

Harms, Sabine, and Clinton D. Winant. "Synthetic subsurface pressure derived from bottom pressure and tide gauge observations." Journal of Atmospheric and Oceanic Technology 11.6 (1994): 1625-1637. 
Hayes, Miles O., and Robert B. Nairn. "Natural Maintenance of Sand Ridges and Linear Shoals on the US Gulf and Atlantic Continental Shelves and the Potential Impacts of Dredging." Journal of Coastal Research 2004, 138-48.

Hoogendoorn, Eric L., and Robert W. Dalrymple. "Morphology, lateral migration, and internal structures of shoreface-connected ridges, Sable Island Bank, Nova Scotia, Canada." Geology 14.5 (1986): 400-403.

Huthnance, John M. "On one mechanism forming linear sand banks." Estuarine, Coastal and Shelf Science 14.1 (1982): 79-99.

Kana, Timothy W. "A mesoscale sediment budget for Long Island, New York."Marine Geology 126.1 (1995): 87-110.

Kana, Timothy W., Julie D. Rosati, and Steven B. Traynum. "Lack of Evidence for Onshore Sediment Transport from Deep Water at Decadal Time Scales: Fire Island, New York.” Journal of Coastal Research 59 (March 2011): 61-75.

Kirincich, Anthony R., and John A. Barth. "Alongshelf Variability of Inner-Shelf Circulation along the Central Oregon Coast during Summer." Journal of Physical Oceanography 39, no. 6 (June 2009): 1380-98.

Kumar, Nirnimesh, George Voulgaris, Jeffrey H. List, and John C. Warner. "Alongshore Momentum Balance Analysis on a Cuspate Foreland: Momentum Balance on A Cuspate Foreland." Journal of Geophysical Research: Oceans 118, no. 10 (October 2013): 5280-95.

Lane, Emily M., and Juan M. Restrepo. "Shoreface-Connected Ridges under the Action of Waves and Currents." Journal of Fluid Mechanics 582 (July 2007): 23.

Large, W. G., and S. Pond. "Open ocean momentum flux measurements in moderate to strong winds." Journal of Physical Oceanography 11.3 (1981): 324-336.

Large, W. G., J. Morzel, and G. B. Crawford. "Accounting for surface wave distortion of the marine wind profile in low-level ocean storms wind measurements." Journal of Physical Oceanography 25.11 (1995): 2959-2971.

LaVelle, J. W., Swift, D. J. P., Gadd, P. E., Stubblefield, W. L., Case, F. N., Brashear, H.R. and Haff, K. W. Fair weather and storm sand transport on the Long Island, New York, inner shelf. Sedimentology, 25 (1978): 823-842.

Lentz, S. J., and C. D. Winant. "Subinertial currents on the southern California shelf." Journal of Physical Oceanography 16.11 (1986): 1737-1750.

Lentz, Steven J. "Current dynamics over the northern California inner shelf." Journal of Physical Oceanography 24.12 (1994): 2461-2478. 
Lentz, Steven J. "Sensitivity of the inner-shelf circulation to the form of the eddy viscosity profile." Journal of Physical Oceanography 25.1 (1995): 19-28.

Lentz, Steve, R.T. Guza, Steve Elgar, Falk Feddersen, and T.H.C. Herbers. "Momentum balances on the North Carolina inner shelf." Journal of Geophysical Research 104, No. C8 (1999). 18205-18226.

Lentz, Steve, and Britt Raubenheimer. "Field observations of wave setup." Journal of Geophysical Research: Oceans 104.C11 (1999): 25867-25875.

Lentz, Steven J., and Melanie R. Fewings. "The Wind- and Wave-Driven Inner-Shelf Circulation." Annual Review of Marine Science 4, no. 1 (January 15, 2012): 317 43.

Liu, Yonggang, and Robert H. Weisberg. "Momentum Balance Diagnoses for the West Florida Shelf." Continental Shelf Research 25, no. 17 (November 2005): 2054 74.

Madsen, Ole Secher, Arlendenovega Satria Negara, Kian Yew Lim, and Hin Fatt Cheong. "Near-bottom flow characteristics of currents at arbitrary angle to 2D ripples." Proceedings of 32nd Conference on Coastal Engineering, July 1-7, 2010, Shanghai, China, 2010.

McBride, Randolph A., and Thomas F. Moslow. "Origin, evolution, and distribution of shoreface sand ridges, Atlantic inner shelf, USA." Marine Geology 97.1 (1991): $57-85$.

Muir, Langley R. "Bernoulli effects on pressure-activated water level gauges."The International Hydrographic Review" 55.2 (1978).

Niedoroda, Alan W., and Donald JP Swift. "Maintenance of the Shoreface by Wave Orbital Currents and Mean Flow: Observations from the Long Island Coast." Geophysical Research Letters 8, no. 4 (1981): 337-40.

Nnafie, A., H. E. de Swart, D. Calvete, and R. Garnier. "Modeling the Response of Shoreface-Connected Sand Ridges to Sand Extraction on an Inner Shelf." Ocean Dynamics 64, no. 5 (May 2014): 723-40.

Nnafie, A., H.E. de Swart, D. Calvete, and R. Garnier. "Effects of Sea Level Rise on the Formation and Drowning of Shoreface-Connected Sand Ridges, a Model Study." Continental Shelf Research 80 (June 2014): 32-48.

Parker, Gerardo, Nestor W. Lanfredi, and Donald JP Swift. "Seafloor response to flow in a southern hemisphere sand-ridge field: Argentine inner shelf." Sedimentary Geology 33.3 (1982): 195-216. 
Peterson, Ernest W., and Joseph P. Hennessey Jr. "On the use of power laws for estimates of wind power potential." Journal of Applied Meteorology 17.3 (1978): 390-394.

Pettigrew, Neal R. "The Dynamics and Kinematics of the Coastal Boundary Layer off Long Island.” Massachusetts Institute of Technology and Woods Hole Oceanographic Institution, 1980.

Rampino, Michael R., and John E. Sanders. "Evolution of the Barrier Islands of Southern Long Island, New York." Sedimentology 28, no. 1 (1981): 37-47.

Rampino, M.R., 1979. Holocene submergence of southern Long Is-land, New York. Nature, 280, 132-134.

Ribas, F., A. Falqués, H. E. de Swart, N. Dodd, R. Garnier, and D. Calvete. "Understanding Coastal Morphodynamic Patterns from Depth-Averaged Sediment Concentration: RIBAS ET AL.." Reviews of Geophysics 53, no. 2 (June 2015): 362-410.

Rosati, Julie D., Mark B. Gravens, and W. Gray Smith. Regional Sediment Budget for Fire Island to Montauk Point, New York, USA. DTIC Document, 1999.

Rosenfeld, L.K., 1983: CODE-1: Moored array and large-scale data report. Woods Hole Oceanographic Institution Tech. Rep. WHOI-83-23, 186 pp.

Schwab, William C., E. Robert Thieler, James R. Allen, David S. Foster, B. Ann Swift, and Jane F. Denny. "Influence of Inner-Continental Shelf Geologic Framework on the Evolution and Behavior of the Barrier-Island System between Fire Island Inlet and Shinnecock Inlet, Long Island, New York." Journal of Coastal Research (2000): 408-22.

Schwab, William C., Wayne E. Baldwin, Cheryl J. Hapke, Erika E. Lentz, Paul T. Gayes, Jane F. Denny, Jeffrey H. List, and John C. Warner. "Geologic Evidence for Onshore Sediment Transport from the Inner Continental Shelf: Fire Island, New York." Journal of Coastal Research 288 (May 2013): 526-44.

Scott, J. T., and G. T. Csanady. "Nearshore currents off Long Island." Journal of Geophysical Research 81.30 (1976): 5401-5409.

Semtner Jr, Albert J., and Yale Mintz. "Numerical simulation of the Gulf Stream and mid-ocean eddies." Journal of Physical Oceanography 7.2 (1977): 208-230.

Soulsby, Richard. Dynamics of marine sands: a manual for practical applications. Thomas Telford, 1997. 
Stommel, Henry, and Ants Leetmaa. "Circulation on the Continental Shelf." Proceedings of the National Academy of Sciences of the United States of America 69, no. 11 (1972): 3380.

Swift, Donald JP, G. Parker, N.W. Lanfredi, G. Perillo, and K. Figge. "Shorefaceconnected sand ridges on American and European shelves: a comparison." Estuarine and Coastal Marine Science7.3 (1978): 257-273.

Swift, D. J. P. and Field, M. E. (1981), Evolution of a classic sand ridge field: Maryland sector, North American inner shelf. Sedimentology 28: 461-482.

Swift, Donald JP, and Thomas F. Moslow. "Holocene Transgression in South-Central Long Island, New York: Discussion.” Journal of Sedimentary Research 52, no. 3 (1982).

van de Meene, Jan WH, and Leo C. van Rijn. "The Shoreface-Connected Ridges along the Central Dutch Coast - part 1: Field Observations." Continental Shelf Research 20, no. 17 (2000): 2295-2323.

van de Meene, Jan WH, and Leo C. van Rijn. "The Shoreface-Connected Ridges along the Central Dutch Coast - part 2: Morphological Modeling." Continental Shelf Research 20, no. 17 (2000): 2325-45.

Vis-Star, N. C., H. E. de Swart, and D. Calvete. "Effect of Wave-Topography Interactions on the Formation of Sand Ridges on the Shelf." Journal of Geophysical Research 112, no. C6 (June 19, 2007).

Warner, John C., Jeffrey H. List, William C. Schwab, George Voulgaris, Brandy Armstrong, and Nicole Marshall. "Inner-Shelf Circulation and Sediment Dynamics on a Series of Shoreface-Connected Ridges Offshore of Fire Island, NY." Ocean Dynamics 64, no. 12 (December 2014): 1767-81.

Wiberg, Patricia L., and Christopher R. Sherwood. "Calculating Wave-Generated Bottom Orbital Velocities from Surface-Wave Parameters." Computers \& Geosciences 34, no. 10 (October 2008): 1243-62.

Winant, Clinton D., and Robert Cruce Beardsley. "A comparison of some shallow wind driven currents." Journal of Physical Oceanography 9.1 (1979): 218-220.

Yankovsky, Alexander E., and Richard W. Garvine. "Subinertial Dynamics on the Inner New Jersey Shelf during the Upwelling Season." Journal of Physical Oceanography 28, no. 12 (1998): 2444-58.

Zimmerman, J. T. F. "Dynamics, diffusion and geomorphological significance of tidal residual eddies." (1981): 549-555. 